\title{
A multi-period multi-objective framework for the synthesis of trigeneration systems in tertiary sector buildings
}

\author{
Eduardo A. Pina*, Miguel A. Lozano, Luis M. Serra \\ GITSE-I3A, Dept. of Mechanical Engineering, University of Zaragoza, Spain. \\ *corresponding author; email: epina@unizar.es.
}

\begin{abstract}
This paper develops a multi-period multi-objective optimization procedure to determine the optimal configuration and operational strategy of a trigeneration system assisted with solar-based technologies and thermal energy storage. The optimization model, formulated as mixed integer linear programming problem, incorporates dynamic operating conditions through time-dependent local climatic data, energy resources, energy demands, electricity prices, and electricity $\mathrm{CO}_{2}$ emission factors. The methodology is applied to a case study of a residential building in Spain. First, the single-objective solutions are obtained, highlighting their fundamental differences regarding the installation of cogeneration (included in the optimal total annual cost solution) and solar-based technologies (included in the optimal total annual $\mathrm{CO}_{2}$ emissions solution). Then, the Pareto curve is generated, and a decision-making approach is proposed to select the preferred trade-off solutions based on the marginal cost of $\mathrm{CO}_{2}$ emissions saved. Additionally, sensitivity analyses are performed to investigate the influence of key parameters concerning energy resources prices, investment costs, and rooftop area. The analyses of the trade-off solutions verify the enormous potential for $\mathrm{CO}_{2}$ emissions reduction, which can reach $32.3 \%$ with only $1.1 \%$ higher costs by displacing cogeneration in favor of the heat pump and the electric grid. Besides, with a modest cost increase of $7.3 \%$, photovoltaic panels are incorporated, promoting an even greater $\mathrm{CO}_{2}$ emissions reduction of $45.2 \%$.
\end{abstract}

Keywords: buildings, $\mathrm{CO}_{2}$ emissions, multi-objective optimization, solar energy, thermal energy storage, trigeneration.

\section{Introduction}

Among the world's largest energy-consuming sectors, the buildings sector has been more and more the focus of research and governmental policies about energy efficiency due to its considerable potential for energy savings, which remains largely untapped ${ }^{1,2}$. In the context of promoting energy efficiency in buildings, it becomes imperative to develop alternative ways of attending the increasing energy demands in an economical and environmentally sound manner. This need is addressed by the European Union's Directive 2010/31/EU ${ }^{2}$ (amended by Directive 2018/844/EU ${ }^{3}$ ), which establishes that member states must improve the energy performance of buildings through high-efficiency alternative energy systems, such as polygeneration, and on-site renewable energy systems. 
Polygeneration systems may be composed of a great number of technologies arranged in various possible configuration modes, among which cogeneration, or Combined Heat and Power (CHP) ${ }^{4,5}$, and trigeneration, or Combined Cooling, Heat and Power (CCHP) ${ }^{6-8}$, are notorious examples. Besides, renewable energy technologies (RETs) based on solar (e.g. photovoltaic panels, solar thermal collectors, hybrid photovoltaic/thermal), wind (e.g. wind turbine generator), and biomass (e.g. biomass boiler), among others, are increasingly being integrated in polygeneration systems, promoting higher flexibility as well as energy, economic, and environmental performances ${ }^{9}$. There are many ways in which solar energy can be effectively deployed to cover multiple energy demands directly (e.g. photovoltaic panels producing electricity; solar thermal collectors producing hot water for space heating) and/or by coupling to heating/cooling technologies (e.g. photovoltaic panels coupled to an electric heat pump for hot water production; solar thermal collectors producing hot water to drive an absorption chiller) ${ }^{10,11}$. Further, thermal energy storage (TES) units are commonly integrated in polygeneration systems to address the non-simultaneity of energy supply and demand characteristic of cogeneration and intermittent generation, such as solar-based RETs ${ }^{12,13}$.

For decades, the optimization of polygeneration systems has been promoting economic and environmental benefits in the industrial and district heating sectors. Industrial applications generally operate at full load, are isolated from the economic market, sometimes with availability of non-commercial residual fuels, and are owned by individual parties ${ }^{14}$. By contrast, energy systems in residential-commercial buildings have key differences regarding ${ }^{15}$ : (i) consumer behavior: devices must often operate at partial load or even be turned-off for some periods due to the variability of energy demands; (ii) economic market: the economic market in which the energy system is inserted often dictates the energy prices, which vary over time and may change in the future; and (iii) ownership: there are often multiple stakeholders, which must agree on how to jointly operate the system.

This calls for an improvement of existing optimization approaches and the development of new ones that take into account the increasingly elaborate problem of the synthesis of polygeneration systems supported with RETs and TES for buildings applications ${ }^{16,17}$. In this regard, the multi-faceted nature of the problem must be tackled: multiple energy resources (renewable and non-renewable), multiple energy products (electricity, steam, hot water, chilled water), multiple technology options (dispatchable, intermittent, storage technologies), and multiple operation periods (hourly and seasonal variations in energy resources, energy demands, and climatic conditions, and temporal variations in energy prices).

The feasibility of a project is commonly evaluated based on its economic performance; for this reason, economic aspects are predominantly considered in optimization studies. The growing concern about sustainability-related issues in recent years is promoting a shift in the decision-making process to also take into consideration environmental and societal aspects ${ }^{18,19}$. It is well known, however, that the minimization of economic costs and the minimization of environmental impacts (e.g. $\mathrm{CO}_{2}$ emissions) are conflicting 
objectives, which means there is no optimal solution fulfilling them both. The matter of conflicting objectives is tackled with multi-objective optimization, in which a set of nondominated solutions (Pareto set) is obtained for which any improvement in one objective results in worsening at least one of the others ${ }^{20}$. Even in purely economic optimization studies, the designer has some leeway to account for environmental aspects, for example by converting them into an economic term in the objective function, such as a carbon emissions tax ${ }^{21-25}$ or a penalty cost for $\mathrm{CO}_{2}$ production ${ }^{26}$, or simply by incorporating a $\mathrm{CO}_{2}$ emissions constraint ${ }^{27,28}$.

The energy system design should carefully represent the dynamic conditions that govern the selection of technologies and the operational planning of the system, which ultimately affect the objective function. It is not uncommon, however, to find studies in the literature that ignore or oversimplify some of these aspects to the detriment of a more realistic solution. There are three important ways in which this oversimplification takes place.

First, the embedded $\mathrm{CO}_{2}$ emissions in the manufacturing process of the technologies are seldom considered, so that the environmental objective function is represented only in terms of the $\mathrm{CO}_{2}$ emissions associated with the consumption of energy resources in the operation of the system. This not only results in an imbalance between the economic and the environmental aspects, in which the former is assessed for both investment and operation costs, while the latter only accounts for operation emissions, but also compromises the accuracy of the environmental optimal, in which technologies are installed as if they had no environmental impact whatsoever. This situation becomes clear when solar-based RETs are considered, such as photovoltaic panels and solar thermal collectors, because they consume an energy resource that has zero cost and zero emissions. Some interesting works that have thoroughly approached $\mathrm{CO}_{2}$ emissions include the Life Cycle Assessment (LCA) optimization of a solar-assisted hybrid CCHP system ${ }^{29}$, the multi-objective optimizations based on economic and environmental aspects of a renewable hybrid CHP system ${ }^{30}$ and a CCHP system ${ }^{31}$, and the technoeconomic and environmental design of small scale microgrids ${ }^{32}$.

Second, to the best of the authors' knowledge, time-based electricity $\mathrm{CO}_{2}$ emission factors have never been taken into account in energy systems optimization studies for buildings applications. It is well-known that the power dispatch is a dynamic process in which the electric generation of different types of power plants must be carefully coordinated to meet the current electricity demand in a certain region/country. Depending on the resource consumed and the power plant type, the produced electricity will have different $\mathrm{CO}_{2}$ emissions content. It should prove straightforward to acknowledge that the electricity available in the electric grid will present fluctuating $\mathrm{CO}_{2}$ emissions content depending on the dispatch at the considered time interval. Therefore, in the same way that the polygeneration system's operational planning adjusts to current economic conditions in the economic optimal solution, such as different hourly electricity prices, so it responds to current environmental conditions in the environmental optimal solution, such as fluctuating grid electricity $\mathrm{CO}_{2}$ emissions. The importance of an appropriate characterization of the electricity greenhouse gas $(\mathrm{GHG})$ emission factors to evaluate the 
environmental performance of energy systems has been demonstrated by Voorspools and D'haeseleer ${ }^{33}$ and Haeseldonckx et al. ${ }^{34}$ for CHP systems in Belgium; Messagie et al. ${ }^{35}$ performed the hourly LCA of electricity production in Belgium; Gordon and Fung 36 estimated the hourly emission factors in Ontario, Canada, for the integration of RETs; Kopsakangas-Savolainen et al. ${ }^{37}$ calculated hourly-based GHG emission factors of the electricity produced in Finland and used these values to estimate potential emissions savings in households and companies; Khan et al. ${ }^{38}$ analyzed the time-varying carbon intensity of electricity in New Zealand; Kelley et al. ${ }^{39}$ proposed a novel scheduling scheme to minimize GHG emissions production for industrial users taking into account time-based information on the power generation mix; and Baumgärtner et al. ${ }^{40}$ developed a method for the design of low-carbon utility systems considering time-dependent grid electricity emissions and applied it to the case study of a chemical plant building. Even though it is true that sufficiently accurate data is difficult to obtain, all consulted energy systems optimization studies consider annual average values for the electricity $\mathrm{CO}_{2}$ emissions, thus completely ignoring the dynamic interaction between the energy system and the electric grid as well as the potential benefits. Nevertheless, it is also interesting to analyze the various methods employed in the literature to determine the average $\mathrm{CO}_{2}$ emission factors: the most common approach is to consider the electricity power mix of a region or a country ${ }^{31,41,42,43,44,45,46}$, but Casisi et al. ${ }^{47}$ adopted the region's main thermoelectric plant, Wang et al. ${ }^{29}$ considered a coal power plant, and Conci et al. ${ }^{48}$ employed the average between the measured value in 2015 and the forecast value for 2050 .

Third, several studies disregard the effect of dynamic climatic conditions, such as hourly and seasonal variations in the ambient temperature and solar radiation, on the performance of solar-based RETs. A temporal and dynamic approach to the operation of solar-based RETs (e.g. solar thermal collectors and photovoltaic panels) is needed to enhance the optimization procedure and the benefits that can be derived from their integration in energy systems. In the literature, an appropriate integration of solar-based RETs has been effectively applied, for example, in the economic optimization of a CHP system for a commercial building in Portugal ${ }^{49}$, a micro-CHP system for a residential application in Italy ${ }^{50}$, and a CCHP system for a commercial building in Switzerland ${ }^{28}$; and in the multi-objective optimization of a distributed CHP system considering economic and environmental aspects ${ }^{47}$, a CCHP system considering economic and exergetic aspects ${ }^{26}$, and a distributed energy system for a residential-commercial district in Beijing considering energy cost, energy consumption and energy losses ${ }^{51}$.

The aim of this paper is to elaborate a mathematical model for the multi-objective synthesis of trigeneration systems assisted with solar-based RETs and TES from economic and environmental viewpoints. Then, the methodology is applied to the case study of a multi-family building in Zaragoza, Spain.

The main contribution of this paper is the proposal of a relatively simple optimization model that encapsulates the great complexity of the synthesis problem. This is achieved by appropriately representing in the same model: (i) economic and environmental aspects: 
the objective functions are represented with the same level of model detail, that is, both economic and environmental objective functions account for the costs and the $\mathrm{CO}_{2}$ emissions of installing and operating the system; (ii) electricity prices and $\mathrm{CO}_{2}$ emissions: apart from considering hourly electricity prices, hourly grid electricity $\mathrm{CO}_{2}$ emissions factors are elaborated and employed in the optimization model; and (iii) climatic conditions: the hourly ambient temperature and hourly solar radiation are reflected in the dynamic operation of the system, as well as their effect on technologies' performances. Additionally, another relevant contribution of this paper is the proposal of a decisionmaking approach for the selection of the preferred trade-off solutions in the Pareto set based on the marginal cost of the $\mathrm{CO}_{2}$ emissions saved.

\section{Multi-objective synthesis framework of energy supply systems}

Given the considerable complexities of polygeneration systems assisted with RETs and TES for buildings applications, an optimization framework is a useful means to approach the problem by gathering the pertinent information and guiding the designer through each step. Achieving the full potential of polygeneration requires an optimization procedure that simultaneously addresses the two fundamental issues of the synthesis of the plant configuration (what technology types should be installed to produce the required energy services and what are their installed capacity) and the optimal operational strategy (what is the suitable operation load of the technologies and the corresponding consumption of energy resources in each time interval) ${ }^{52,53}$. Mathematical optimization has been extensively applied in the synthesis, design, operation, and control of energy systems ${ }^{20,54}$. This approach involves the definition of a superstructure of potential technologies and the search for a solution to the objective function (e.g. minimize total annual cost, minimize total annual $\mathrm{CO}_{2}$ emissions, maximize primary energy savings). Optimization models for polygeneration systems have been reviewed by Chicco and Mancarella ${ }^{9}$ and Ünal et al. ${ }^{55}$, indicating the solution method, the objective function, the time scale, among others.

This paper develops a multi-objective optimization model using MILP formulation to assess the optimal configuration and multi-period operating strategy, from the economic and environmental viewpoints, of a trigeneration system including RETs and TES that produces electricity, heat, and cooling. The objective functions considered herein are the minimum total annual cost and the minimum total annual $\mathrm{CO}_{2}$ emissions, which are composed of a fixed (or capital) term relative to the installation of the technologies, and a variable (or operation) term relative to the operation of the system.

The model uses binary variables to impose structural (e.g. permission to install technologies or not) and operational (e.g. operating modes of technologies) restrictions, and continuous variables to represent the energy, economic, and environmental flows. The multi-period operation reflects the way in which the production of energy services is adjusted, within established limits, to dynamic operating conditions, such as the variability of climatic conditions, energy resources, and energy demands, as well as changes in energy resources prices, $\mathrm{CO}_{2}$ emission factors, and technologies' 
performances. Also, local regulatory aspects involving, for example, the installation of cogeneration facilities and the interconnection with the electric grid, are considered. The single-objective solutions provide the minimum total annual cost and minimum total annual $\mathrm{CO}_{2}$ emissions of installing and operating the system, a breakdown of capital and operation costs and emissions, as well as the hourly, monthly and annual energy flows. In turn, the multi-objective trade-off solutions are indicated in the Pareto curve.

As depicted Figure 1, the framework consists of four main steps, which will be explained through the rest of the paper: (i) superstructure definition in accordance with the defined energy design targets and the available energy resources; (ii) data collection and elaboration regarding the established optimization criteria and objective functions; (iii) mathematical model development in line with the nature of the problem (i.e. single- or multi-objective optimization); and (iv) optimal decision-making.

It is worth mentioning that this approach is intended as a pre-design method: the solutions obtained do not correspond to final designs; on the contrary, they provide the basis for a subsequent more in-depth optimization process, which establishes the actual number of devices and their corresponding installed capacities and takes into account part-load operating conditions.

\section{Solar-assisted trigeneration system}

Based on the multi-objective synthesis framework depicted in Figure 1, Section 3.1 presents the superstructure of the system (step 1), and Section 3.2 collects and elaborates the input data used by the optimization model (step 2).

\subsection{Superstructure of the trigeneration system}

As a first approach to the design problem, the superstructure of the energy system must be defined 56,57. Basically, the superstructure consists of a variety of potential technologies, as well as the feasible connections between them, that must match the required energy demands. As a result of the optimization process, the superstructure is reduced to the optimal configuration.

Figure 2 shows the superstructure of the trigeneration system, which consists of a cogeneration module GE (internal combustion engine and heat recovery system), photovoltaic panels PV, flat-plate solar thermal collectors ST, a natural gas boiler GB, a reversible heat pump HP, a single-effect absorption chiller ABS, and two TES units, one for hot water TSQ and another for chilled water TSR. The energy resources available to the system include both renewable (solar radiation $F_{p v}$ and $F_{s t}$ ) and conventional (natural gas $F_{p}$ and electricity purchased from the electric grid $E_{p}$ ) kinds. The system is designed to attend the consumer center's electricity $E_{d}$, heating $Q_{d}$, and cooling $R_{d}$ demands. The sale of electricity $E_{s}$ is allowed. Some equipment can produce heat at different temperature levels: $60{ }^{\circ} \mathrm{C}$ (low-temperature heat), for the heating demand, and $85{ }^{\circ} \mathrm{C}$ (high-temperature heat), to produce cooling in the ABS. 
The GE produces electricity $W_{c}$ and heat $Q_{c c}$ and $Q_{c r}$ from natural gas $F_{c}$; also, heat dissipation $Q_{c l}$ is possible. Heat $Q_{a c}$ and $Q_{a r}$ is produced in the GB from natural gas $F_{a}$. The PV produces electricity $W_{p v}$ from the solar radiation $F_{p v}$. The ABS produces chilled water $R_{a b s}$ from the high-temperature heat $Q_{a b s}$; there is an auxiliary consumption of electricity $W_{a b s}$. The HP and the ST are particular cases because there are two possible operating modes depending on the month of the year:

- In the summer months (June-September), the heat pump is in cooling mode HPR, producing cooling $R_{h p}$ from electricity $W_{h p}$, and the ST are in high-temperature mode, producing high $Q_{s t r}$ and low $Q_{s t c}$ temperature heat from the solar radiation $F_{s t}$;

- For the rest of the year, the heat pump is in heating mode HPQ, producing lowtemperature heat $Q_{h p}$ from electricity $W_{h p}$, and the ST operates in low-temperature mode, producing only low-temperature heat $Q_{s t c}$.

In both operating modes of the ST, solar heat can be dissipated into the environment $Q_{\text {st }}$, if necessary. Concerning the thermal energy storage tanks, the TSQ is charged $Q_{i n}$ and discharged $Q_{o u t}$ with low-temperature heat, while the TSR is charged $R_{\text {in }}$ and discharged $R_{\text {out }}$ with cooling. For both devices, charge and discharge cannot take place simultaneously. It is assumed that the energy losses $Q_{s}$ and $R_{s}$ in the TES units are proportional to the energy stored $S_{q}$ and $S_{r}$ in the previous time interval.

\subsection{Data collection and elaboration}

Having defined the superstructure of the system, the next step is to gather additional and more specific data that will serve as input to the optimization model. Clearly, this step plays a key role in the design of energy systems because the quality of the data directly affects the credibility of the results obtained.

The input data used by the model is described throughout this Section: First, a brief description of the consumer center is given in Section 3.2.1, followed by the hourly energy demands for the representative days of the months of the year in Section 3.2.2. The technical parameters of the candidate technologies in the superstructure are presented in Section 3.2.3. Finally, Sections 3.2.4 and 3.2.5 provide information regarding the criteria chosen for the multi-objective optimization procedure, namely economic and environmental data, respectively. The reader is referred to Pina ${ }^{58}$ for a complete description of the data presented herein.

\subsubsection{Consumer center description}

The case study analyzed herein consists of a multi-family residential building complex located in Zaragoza (latitude $41.6^{\circ}$ ), Spain. There are 100 dwellings with $100 \mathrm{~m}^{2}$ of surface area distributed among five identical buildings. Considering the geometry of the residential buildings, a total rooftop area $A A=2000 \mathrm{~m}^{2}$ is available for the installation of photovoltaic panels and solar thermal collectors. 


\subsubsection{Energy demands}

The energy demands of the consumer center represent the core of the design procedure, as they provide the necessary information to (i) select the types of technologies that must be installed; (ii) size them; and (iii) define the appropriate operating strategies following the demands' hourly and seasonal variations. Therefore, the estimation of the energy demand data plays a critical role in ensuring the economic and environmental feasibility of the trigeneration system.

The energy demands required by the consumer center correspond to electricity, heating, and cooling. The heating demand is composed of both domestic hot water (DHW) and space heating $(\mathrm{SH})$ loads, which are supplied to the consumer center at $60^{\circ} \mathrm{C}$. The cooling demand corresponds to chilled water at $7{ }^{\circ} \mathrm{C}$. Moreover, the electricity demand excludes the consumption of electricity for thermal production, e.g. electric chiller for cooling production, electric heat pump for heat production; thus, the electricity demand considers only the dwellings' electric consumption for home appliances, lighting, etc.

The study covers the period of one year, which is composed of 12 representative days $d$ of 24 hourly periods $h$. In this way, each representative day is attributed to one month. As the name implies, these representative days only account for typical energy demand values, which may hide, to some extent, sporadic peak demands. In order to take into account these extreme demand conditions, two extra representative days were included, one for the winter and another for the summer.

The energy demands were estimated for the representative days of the months of the year based on: (i) climatic data for the geographical location in Spain (e.g. hourly ambient air temperature and monthly cold water temperature of the supply network); (ii) building characteristics (e.g. number of dwellings, surface area, occupancy rate); (iii) reference values of annual energy consumption; and (iv) monthly and hourly energy demand profiles. The annual energy demands are 254.96 MWh of electricity, 573.50 MWh of heating, and $113.99 \mathrm{MWh}$ of cooling. Table 1 presents the daily energy demands for the 12 representative days corresponding to the months of the year, plus the 2 extremedemand representative days.

\subsubsection{Technical data}

The technical, economic, and environmental parameters of the technologies included in the superstructure defined in Section 3.1 are based on real, commercially available devices, which were carefully selected to suit appropriate capacity ranges estimated from the consumer center's energy demands. The main technical parameters of the technologies are presented in Table 2, as described by Pina ${ }^{58}$.

The technologies can be operated between zero and nominal load with no effect on their performances. However, based on information obtained from the manufacturers' catalogues, the performances of some technologies have been adjusted for off-nominal operating conditions, such as different operating modes, in the case of the reversible heat 
pump HP, and hourly ambient temperature, in the case of the HP and single-effect absorption chiller ABS.

The PV unit production $x_{p v}(d, h)$ in $\mathrm{kW} / \mathrm{m}^{2}$ is determined by Eq. (1) ${ }^{59}$.

$x_{p v}(d, h)=\frac{P_{p v}}{A_{p v}} \cdot \frac{F_{p v}(d, h)}{Q_{r, S R C}} \cdot F_{t o p}(d, h) \cdot \eta_{e}$

where $F_{p v}(d, h)$ is the hourly solar radiation on tilted PV area, the efficiency of powerconditioning equipment is $\eta_{e}=0.9$, and $F_{\text {top }}(d, h)$ is the hourly temperature correction factor. The $F_{p v}(d, h)$ was estimated using the isotropic sky model as described in ${ }^{59,60}$, considering a $35^{\circ}$ tilt and $0^{\circ}$ orientation azimuth south. The $F_{\text {top }}(d, h)$ is calculated by

$F_{\text {top }}(d, h)=1+\mu_{T} \cdot\left(T_{c, p v}(d, h)-T_{c, S R C}\right)$

where $T_{c, p v}(d, h)$ is the PV hourly cell temperature, which, in turn, is given by

$$
\begin{aligned}
T_{c, p v}(d, h)= & T a(d, h)+\left(T_{c, N O C T}-T_{a, N O C T}\right) \cdot \frac{F_{p v}(d, h)}{Q_{r, N O C T}} \\
& \cdot\left(1-\frac{\eta_{p v} \cdot F_{t o p}(d, h)}{0.9}\right)
\end{aligned}
$$

where $\operatorname{Ta}(d, h)$ is the hourly ambient temperature.

According to the methodology described by Guadalfajara et al. ${ }^{61}$, the Erbs' correlation for ambient temperature ${ }^{62}$ was used to estimate the $T a(d, h)$ for Zaragoza, Spain, using the monthly mean temperatures obtained from AEMET ${ }^{63}$.

As previously mentioned, the ST is considered to operate either at low-temperature $\left(T_{s t}=\right.$ $\left.60{ }^{\circ} \mathrm{C}\right)$, supplying hot water to attend the heating demand, or at high-temperature $\left(T_{s t}=\right.$ $\left.80^{\circ} \mathrm{C}\right)$, supplying hot water to drive the ABS. The ST unit production $x_{s t}(d, h)$ in $\mathrm{kW} / \mathrm{m}^{2}$ is determined by

$$
\begin{gathered}
x_{s t}(d, h)=\operatorname{Max}\left(k_{0} \cdot F_{s t}(d, h)-k_{1} \cdot\left(T_{s t}-T a(d, h)\right)-k_{2}\right. \\
\left.\cdot\left(T_{s t}-T a(d, h)\right)^{2} ; 0\right)
\end{gathered}
$$

where $F_{s t}(d, h)$ is the solar radiation on tilted ST area $\left(30^{\circ}\right.$ tilt and $0^{\circ}$ orientation azimuth south), and the ST working temperature $T_{s t}$ is that of the corresponding operating mode.

\subsubsection{Economic data}

The bare module cost $C I$ of each technology $t$ corresponds to the unit investment cost adjusted by a simple module factor, which takes into account transportation, installation, connection, insulation costs, among others. The $C I$ values presented in Table 3 were estimated from manufacturers' catalogues and from the literature, as described by Pina 58. The optimization model determines which technologies should be selected and their corresponding installed capacities. The total investment cost of the plant is: (i) increased 
by a factor of $20 \%\left(f_{I C}=0.20\right)$, which takes into account indirect costs of the plant, such as engineering and supervision expenses, legal expenses, contractor's fees and contingencies; and (ii) multiplied by the amortization and maintenance factor $f_{\text {am }}=0.15$ $\mathrm{yr}^{-1}$, composed of the maintenance and operation costs factor $\left(0.0325 \mathrm{yr}^{-1}\right)$ and the capital recovery factor $\left(0.1175 \mathrm{yr}^{-1}\right)$, obtained for an interest rate of $0.10 \mathrm{yr}^{-1}$ and an operational lifetime $n y r=20 \mathrm{yr}$.

In Spain, both electricity and natural gas markets are liberalized, which means consumers are free to choose from the available local distributors or to remain connected to the regulated market. The gas and electricity prices considered herein were taken from the local distributor EDP ${ }^{64}$ under the free market modality and include taxes. The purchase price of natural gas is $c_{g}=0.0566 € / \mathrm{kWh} \mathrm{LHV}$. For the purchase price of electricity $c_{e p}$, a time-of-use tariff with three time periods (on-peak, mid-peak, and off-peak) was considered, as shown in Table 4. It was assumed that the selling price of electricity was the same as the purchase price $c_{e p}$.

\subsubsection{Environmental data}

In addition to the economic data, the other aspect considered in the multi-objective optimization procedure concerns the environmental impacts of installing and operating the system, represented by the $\mathrm{CO}_{2}$ equivalent emissions. Analogous to the total annual cost, the total annual $\mathrm{CO}_{2}$ emissions is composed of a fixed (or capital) term, relative to the emissions embodied in the manufacturing of the technologies, and a variable (or operation) term, relative to the emissions generated in the operation of the system, i.e. consumption of natural gas and electricity from the electric grid.

For each technology $t$ from the superstructure, Table 3 presents the unit $\mathrm{CO}_{2}$ emissions $\mathrm{CO} 2 \mathrm{U}$, which expresses the amount of $\mathrm{CO}_{2}$ emissions associated with the manufacturing of the technology per unit of capacity installed. The $C O 2 U$ values of the GE, GB, HP and ABS were estimated from Carvalho ${ }^{65}$; the ST, TSQ and TSR from Guadalfajara ${ }^{66}$; and the PV from Ito et al. ${ }^{67}$.

The $\mathrm{CO}_{2}$ emission factor of natural gas consumption in Spain is $\mathrm{kgCO} 2_{\mathrm{g}}=0.252$ $\mathrm{kgCO}_{2} / \mathrm{kWh}(\mathrm{LHV})^{68}$. In the case of the grid electricity, real-time data on the Spanish power production and the corresponding $\mathrm{CO}_{2}$ emissions are provided by the Red Eléctrica de España (REE) ${ }^{69}$. We have processed this information to obtain the hourly $\mathrm{CO}_{2}$ emission factors $\mathrm{kgCO} e(d, h)$ of the Spanish grid electricity. The result is shown in Figure 3. Selling electricity displaces the consumption of electricity from the electric grid; therefore, the hourly $\mathrm{CO}_{2}$ emissions associated with the electricity sold to the grid were considered to be equal to the emissions associated with the purchased electricity.

\section{Mathematical model}

Having defined the superstructure of the trigeneration system and collected and elaborated the necessary data on the consumer center, the next step is to develop a 
mathematical model representing the behavior and performances of all elements considered in the system. The model developed herein determines the optimal configuration and operating strategy from economic and environmental viewpoints. LINGO ${ }^{70}$ was used to implement and solve the model. A thorough description of the optimization model is provided in Pina ${ }^{58}$.

Some important assumptions have been made to reach a good compromise between model accuracy and computational effort: (i) the hourly energy demands, climatic data (ambient temperature and solar radiation), energy prices, and $\mathrm{CO}_{2}$ emission factors are known before-hand and are considered constant in each time interval; (ii) the technologies can operate between zero and nominal load with no effect on their performances; (iii) the technologies' unit investment costs and unit $\mathrm{CO}_{2}$ emissions are independent from their corresponding installed capacities; (iv) the TES units work as a buffer in which thermal energy is stored (with losses) and consumed later at the required temperature level; and (v) considering the daily cyclical characteristic of the system operation, a daily cyclic operation of the TES units is considered assuming that the storage level by the end of the representative day must return to its initial state of the beginning of that day.

\subsection{Objective functions}

As shown in Eq. (5), the total annual cost $C T E_{\text {tot }}$ involves the following terms: annual fixed cost $C T E_{f i x}$ and annual variable cost $C T E_{\text {var }}$.

Min $C T E_{\text {tot }}=C T E_{\text {fix }}+C T E_{\text {var }}$

The $C T E_{f i x}$ is shown in Eq. (6), in which $P I N(t)$ is the installed capacity of technology $t$.

$C T E_{f i x}=f_{a m} \cdot\left(f_{I C}+1\right) \cdot \sum_{t} C I(t) \cdot \operatorname{PIN}(t)$

The $C T E_{\text {var }}$ consists of the costs relative to the consumption of natural gas $C T E_{\text {gas }}(d, h)$ and electricity cost $C T E_{\text {ele }}(d, h)$ :

$$
\begin{aligned}
& C T E_{\text {var }}=\sum_{d, h} N R Y(d) \cdot\left(C T E_{g a s}(d, h)+C T E_{\text {ele }}(d, h)\right) \\
& C T E_{g a s}(d, h)=c_{g} \cdot F_{p}(d, h) \\
& C T E_{\text {ele }}(d, h)=c_{e p}(d, h) \cdot\left(E_{p}(d, h)-E_{s}(d, h)\right)
\end{aligned}
$$

Likewise, the environmental objective function is the total annual $\mathrm{CO}_{2}$ emissions $\mathrm{CO}_{\text {tot }}$, and it involves the following terms: annual fixed emissions $\mathrm{CO}_{f i x}$ and annual variable emissions $\mathrm{CO} 2_{\text {var }}$.

$\operatorname{Min} C O 2_{\text {tot }}=C O 2_{f i x}+C O 2_{v a r}$

The $C O 2_{f i x}$, is expressed by 
$\mathrm{CO2}_{\text {fix }}=\sum_{t} \operatorname{CO2U}(t) \cdot \operatorname{PIN}(t) /$ nyr

The $\mathrm{CO}_{\text {var }}$ consists of the emissions relative to the consumption of natural gas $\mathrm{CO}_{\text {gas }}(d, h)$ and electricity $\mathrm{CO}_{\text {ele }}(d, h)$ :

$$
\begin{aligned}
& \mathrm{CO2}_{\text {var }}=\sum_{d, h} N R Y(d) \cdot\left(\operatorname{CO2}_{\text {gas }}(d, h)+\mathrm{CO2}_{\text {ele }}(d, h)\right) \\
& \mathrm{CO2}_{\text {gas }}=\mathrm{kgCO}_{g} \cdot F_{p}(d, h) \\
& \mathrm{CO2}_{\text {ele }}=\operatorname{kgCO2}_{e}(d, h) \cdot\left(E_{p}(d, h)-E_{s}(d, h)\right)
\end{aligned}
$$

\subsection{System constraints}

The constraints of the objective functions include installed capacity limits, production restrictions, energy balances, and structural and operation restrictions, described in the following subsections.

\subsubsection{Installed capacity limits}

The installed capacity $\operatorname{PIN}(t)$ is limited to the maximum installable capacity $\operatorname{PIN} N_{M A X}(t)$, given in Table 3.

$\operatorname{PIN}(t) \leq y I N S(t) \cdot \operatorname{PIN} N_{M A X}(t)$

where the binary variable $y I N S(t)$ expresses the permission to install or not the technology $t$.

Specific capacity limits apply to the reversible heat pump HP, photovoltaic panels PV, and flat-plate solar thermal collectors ST. In the case of the HP, its nominal capacity PIN and maximum installable capacity $P I N_{M A X}$ have different values depending on the operating mode (heating HPQ or cooling HPR), which are related through the $R C A P_{r q}$, given in Table 3.

$$
\begin{aligned}
& P I N_{M A X}(H P R)=R C A P_{r q} \cdot P I N_{M A X}(H P Q) \\
& P I N(H P R)=R C A P_{r q} \cdot P I N(H P Q)
\end{aligned}
$$

In the case of the PV and ST, their installation is limited to the rooftop area available $A A$, as expressed by Eq. (18). The ratios $r p v$ and $r s t$ are used to relate the rooftop area occupied per $\mathrm{m}^{2}$ of module installed.

$r p v \cdot P I N(P V)+r s t \cdot P I N(S T) \leq A A$

\subsubsection{Production restrictions}

The candidate technologies' production restrictions are described below.

\section{Cogeneration module (GE)}


Electricity production $W_{c}(d, h)$ is limited to $P I N(G E)$ (Eq. (19)). Natural gas $F_{c}(d, h)$ conversion into electricity depends on the GE electric power efficiency $\alpha_{w}$ (Eq. (20)); likewise, the heat production depends on the GE thermal efficiency $\alpha_{q}$ (Eq. (21)). The total cogenerated heat $Q_{c x}(d, h)$ produced by the technology corresponds to the sum of the low-temperature $Q_{c c}(d, h)$, high-temperature $Q_{c r}(d, h)$, and wasted $Q_{c l}(d, h)$ heat flows (Eq. (22)).

$$
\begin{aligned}
& W_{c}(d, h) \leq P I N(G E) \\
& \alpha_{w} \cdot F_{c}(d, h)-W_{c}(d, h)=0 \\
& \alpha_{q} \cdot F_{c}(d, h)-Q_{c x}(d, h)=0 \\
& Q_{c x}(d, h)=Q_{c c}(d, h)+Q_{c r}(d, h)+Q_{c l}(d, h)
\end{aligned}
$$

\section{Gas boiler (GB)}

Heat production $Q_{a x}(d, h)$ is limited to $P I N(G B)$ (Eq. (23)). In turn, the fuel conversion into heat is a function of the GB thermal efficiency $\eta_{q}$ (Eq. (24)). The heat flow $Q_{a x}(d, h)$ is the sum of the low-temperature $Q_{a c}(d, h)$ and the high-temperature $Q_{a r}(d, h)$ heat flows (Eq. (25)).

$$
\begin{aligned}
& Q_{a x}(d, h) \leq P I N(G B) \\
& \eta_{q} \cdot F_{a}(d, h)-Q_{a x}(d, h)=0 \\
& Q_{a x}(d, h)=Q_{a c}(d, h)+Q_{a r}(d, h)
\end{aligned}
$$

\section{Reversible heat pump $(H P)$}

The binary variables $y H P Q(d)$ and $y H P R(d)$ establish the HP's operating mode. The heat $Q_{h p}(d, h)$ produced by the HPQ is limited to its installed capacity, which must be adjusted by the factor $f C A P_{h p q}(d, h)$ (Eq. (26)). Analogously, the chilled water $R_{h p}(d, h)$ produced by the HPR is limited to its installed capacity and adjusted by the factor $f C A P_{h p r}(d, h)$ (Eq. (27)). As previously mentioned, these adjustment factors take into account off-nominal operation conditions.

$$
\begin{aligned}
& Q_{h p}(d, h) \leq y H P Q(d) \cdot f C A P_{h p q}(d, h) \cdot P I N(H P Q) \\
& R_{h p}(d, h) \leq y H P R(d) \cdot f C A P_{h p r}(d, h) \cdot P I N(H P R)
\end{aligned}
$$

The relation between the consumed electricity $W_{h p}(d, h)$ and the produced heat $Q_{h p}(d, h)$ (in the case of HPQ) or chilled water $R_{h p}(d, h)$ (in the case of HPR) are shown in Eqs. (28) and (29), respectively.

$$
\begin{aligned}
& Q_{h p}(d, h)=f C O P_{h p q}(d, h) \cdot \operatorname{COP}_{h p q}(H P Q) \cdot W_{h p}(d, h) \\
& R_{h p}(d, h)=f E E R_{h p r}(d, h) \cdot E E R_{h p r}(H P R) \cdot W_{h p}(d, h)
\end{aligned}
$$

\section{Single-effect absorption chiller (ABS)}

Cooling production $R_{a b s}(d, h)$ is limited to $\operatorname{PIN}(A B S)$. The effect of varying ambient temperature is taken into account through the adjustment factor $f C A P_{a b s}(d, h)$. 
$R_{a b s}(d, h) \leq f C A P_{a b s}(d, h) \cdot P I N(A B S)$

As shown in Eq. (31), the $C O P_{a b s}$ relates heat consumption $Q_{a b s}(d, h)$ and chilled water production $R_{a b s}(d, h)$.

$C O P_{a b s} \cdot Q_{a b s}(d, h)-R_{a b s}(d, h)=0$

In addition, an auxiliary electricity consumption $W_{a b s}(d, h)$ was considered for the operation of the absorption chiller, as expressed by

$W_{a b s}(d, h)-k w a b s \cdot R_{a b s}(d, h)=0$

Photovoltaic panels $(P V)$

Electricity production $W_{p v x}(d, h)$ is calculated based on the hourly specific production $x_{p v}(d, h)$, as shown in Eq. (33). From the total electricity produced $W_{p v x}(d, h)$, a part is used by the system $W_{p v}(d, h)$ and, if necessary, a part may be wasted $W_{p v l}(d, h)$ (Eq. (34)).

$W_{p v x}(d, h)-x_{p v}(d, h) \cdot P I N(P V)=0$

$W_{p v x}(d, h)=W_{p v}(d, h)+W_{p v l}(d, h)$

Flat-plate solar thermal collectors (ST)

The binary variables $y S T Q(d)$ and $y S T R(d)$ establish whether the ST is operating at lowtemperature or at high-temperature, respectively. The total heat produced $Q_{s t x}(d, h)$ by the ST is assessed for the operation mode in the corresponding representative day (Eq. (35)). Eq. (36) expresses the three components of the total heat produced, namely hightemperature heat $Q_{s t r}(d, h)$, low-temperature heat $Q_{s t c}(d, h)$, and dissipated heat $Q_{s t l}(d, h)$. An additional restriction is introduced by Eq. (37), which limits the heat production $Q_{s t r}(d, h)$ in high-temperature operation to the installed capacity $P I N(S T)$ and to the hourly specific production per $\mathrm{m}^{2} x_{s t r}(d, h)$.

$Q_{s t x}(d, h)-\left(y S T Q(d) \cdot x_{s t q}(d, h)+y S T R(d) \cdot x_{s t r}(d, h)\right) \cdot P I N(S T)=0$

$Q_{s t x}(d, h)=Q_{s t r}(d, h)+Q_{s t c}(d, h)+Q_{s t l}(d, h)$

$Q_{s t r}(d, h) \leq y S T R(d) \cdot x_{s t r}(d, h) \cdot \operatorname{PIN}(S T)$

\section{TES units}

Regarding the hot water storage tank TSQ, the energy stored $S_{q}(d, h)$ is limited to $\operatorname{PIN}(T S Q)$ :

$S_{q}(d, h) \leq P I N(T S Q)$

Energy losses $Q_{s}(d, h)$ are calculated as shown in Eq. (39).

$Q_{s}(d, h)=\operatorname{fpacu} Q \cdot S_{q}(d, h-1)$

The energy balance in the TSQ is given by Eq. (40). 
$S_{q}(d, h-1)+\left(Q_{\text {in }}(d, h)-Q_{\text {out }}(d, h)-Q_{s}(d, h)\right) \cdot N H P(h)-S_{q}(d, h)=0$

The same considerations are made for the chilled water storage tank TSR, thus obtaining the following equations:

$S_{r}(d, h) \leq P I N(T S R)$

$R_{s}(d, h)=$ fpacuR $\cdot S_{r}(d, h-1)$

$S_{r}(d, h-1)+\left(R_{\text {in }}(d, h)-R_{\text {out }}(d, h)-R_{s}(d, h)\right) \cdot N H P(h)-S_{r}(d, h)=0$

\subsubsection{Energy balances}

Equations (44)-(48) express the electricity, natural gas, low-temperature heat, hightemperature heat, and cooling balances, respectively.

$$
\begin{aligned}
& E_{p}(d, h)+W_{c}(d, h)+W_{p v}(d, h)-E_{s}(d, h)-W_{h p}(d, h)-W_{a b s}(d, h) \\
& \quad-E_{d}(d, h)=0 \\
& F_{p}(d, h)-F_{c}(d, h)-F_{a}(d, h)=0 \\
& Q_{c c}(d, h)+Q_{a c}(d, h)+Q_{h p}(d, h)+Q_{s t c}(d, h)+Q_{o u t}(d, h)-Q_{i n}(d, h) \\
& \quad-Q_{d}(d, h)=0 \\
& Q_{c r}(d, h)+Q_{a r}(d, h)+Q_{s t r}(d, h)-Q_{a b s}(d, h)=0 \\
& R_{a b s}(d, h)+R_{h p}(d, h)+R_{\text {out }}(d, h)-R_{\text {in }}(d, h)-R_{d}(d, h)=0
\end{aligned}
$$

\subsubsection{Structural and operational restrictions}

The MILP model employs binary variables to represent structural conditions, such as the permission to install the candidate technologies in the superstructure, as expressed by Eq. (15) with the binary variable $y I N S$, and operational conditions, such as: (i) the operation modes of the HP, expressed by the binary variables $y H P Q$ and $y H P R$ (Eqs. (26) and (27)), and ST, expressed by the binary variables $y S T Q$ and $y S T R$ (Eqs. (35) and (37)); (ii) electric grid conditions, such as permission to purchase electricity from the electric grid and the permission to sell electricity, with the additional condition that electricity purchase and sale cannot take place simultaneously; and (iii) the TES units operating strategy, in which the charging and discharging cannot take place simultaneously.

\section{Single-objective optimization}

As a first approach to the multi-objective optimization, the objective functions were assessed individually. The single-objective optimization solutions obtained are analyzed and compared, thus providing essential information for the determination of the trade-off solutions between them. The main results are shown in Table 5. The following subsections provide an in-depth explanation of the results.

\subsection{Economic cost optimization}


The main results obtained for the total annual cost optimal solution are shown in Table 5, including both the capital (installed technologies) and the operation (energy resources consumption) aspects of the system. This information is complemented by Figure 4, which depicts the optimal configuration of the system, indicating the installed capacities of the technologies and the annual energy flows.

The minimum total annual cost $C T E_{\text {tot }}$ of $105,066.9 € / \mathrm{yr}$ was obtained, $72 \%$ of which corresponds to energy consumption costs and $28 \%$ to the investment cost. The corresponding total annual $\mathrm{CO}_{2}$ emissions $\mathrm{CO}_{\text {tot }}$ was equal to $155,065.7 \mathrm{kgCO}_{2} / \mathrm{yr}$, the greatest part $(98 \%)$ being attributed to the purchased electricity and natural gas.

The optimal total annual cost solution included the following technologies: GE, GB, HP, ABS, TSQ, and TSR. It should be noted that installed capacity of the TSQ was negligible $(0.4 \mathrm{kWh})$. The breakdown of the annual investment cost shows that the HP, ABS, and GB accounted for $47 \%, 29 \%$, and $10 \%$, respectively. Concerning the annual fixed $\mathrm{CO}_{2}$ emissions, the HP also accounts for the largest share (46\%), followed by the ABS (28\%), and the TSR (21\%). As regards the annual consumption of energy resources, the optimal total annual cost solution heavily relies on natural gas and electricity from the electric grid. Furthermore, all the electricity produced by the system (i.e. in the cogeneration module GE) is consumed, so there is no sale to the grid. The annual operation cost shows that the purchased electricity accounts for $73 \%$, while natural gas consumption was responsible for the remaining $27 \%$. Conversely, the associated $\mathrm{CO}_{2}$ emissions are mostly attributed to the natural gas consumption $(60 \%)$.

Concerning the system's operational planning, the GE, GB, and HP operate all year round, while the ABS and TSR operate only during the summertime (from June to September), when cooling is required. Considering the electricity consumption (internal consumption and electricity demand), $91.6 \%$ is covered by the electric grid. Even though the installed capacity of GE is relatively small, it operates with the highest load factor (88\%) compared to the other technologies. Regarding the heat production, the HP and GB account for $48.4 \%$ and $38.6 \%$, respectively. The GB, on the other hand, presents a relatively low load factor $(13 \%)$, as it operates mostly during the wintertime, when the heating demand is higher. Cooling production takes place almost entirely in the HP (91.7\%), while the ABS is only used to attend peak demands in July and August with heat produced by the GB, hence the low load factor (2\%). The TSR stores $4.5 \%$ of the total cooling produced by system. The dual operation of the HP (i.e. heating mode and cooling mode) allows for a prolonged operation throughout the year, resulting in a load factor of $50 \%$.

The annual energy flows are obtained by consolidating the hourly operation of the system. Two examples are provided: Figure 5 presents the optimal hourly electricity and heating productions of the system in January, and Figure 6 presents the optimal hourly electricity, heating, and cooling productions in July.

In January, the consumer center's energy demands consist of electricity $E_{d}$ and heating $Q_{d}$. The hourly electricity production is characterized by purchase from the electric grid 
$E_{p}$ and by a continuous operation of the GE throughout the day, producing cogenerated electricity $W_{c}$ and heat $Q_{c c}$. It is interesting to notice the increase in $E_{p}$ at hours 7 and 8 , which corresponds to: (i) the end of the off-peak electricity rate (see Table 4); and (ii) the beginning of the heating demand $Q_{d}$. Apart from the electricity demand, electricity is also consumed by the HP from hour 6 to 20 for heat production $Q_{h p}$. The heat production is also supported by the GB with $Q_{a c}$ and $Q_{a r}$.

In the month of July, electricity $E_{d}$, heating $Q_{d}$ and cooling $R_{d}$ are required by the consumer center. The GE operation is similar to the one in January, and the system also purchases electricity $E_{p}$ throughout the day. The heat production is covered by the GE and the GB. The HP provides most of the required cooling, leaving the ABS to cover the peak demands with heat from the GB (e.g. hours 15 to 17). It is interesting to notice that even though the cooling demand starts at hour 12, its production begins earlier in the day at hour 8. This hour corresponds to the end of the off-peak electricity rate period (see Table 4), so the system can take advantage of the TSR to store cooling produced with cheaper electricity and use it at hour 15 to displace the more expensive operation of the ABS.

\subsection{Environmental optimization}

Analogous to the economic cost optimization, Table 5 and Figure 7 show the results obtained for the optimal environmental solution.

The minimum total annual $\mathrm{CO}_{2}$ emissions $\mathrm{CO}_{\text {tot }}$ equal to $74,240.1 \mathrm{kgCO}_{2} / \mathrm{yr}$ was obtained, $83 \%$ of which being attributable to the annual operation of the system and the remaining $17 \%$ to the technologies manufacturing and installation. The corresponding total annual cost $C T E_{\text {tot }}$ was equal to $137,630.2 € / \mathrm{yr}$, being $61 \%$ related to the investment cost and $39 \%$ to the annual operation of the system.

The optimal environmental solution included the following technologies: PV, ST, GB, HP, ABS, and TSQ. The installation of PV and ST occupied all the rooftop area available. Regarding the annual investment cost, the three highest shares are attributable to the installation of ST (30\%), HP (28\%), and PV (26\%). By contrast, the three highest shares of the annual $\mathrm{CO}_{2}$ emissions are: PV (52\%), TSQ (19\%), and HP (17\%). As regards the annual consumption of energy resources, the optimal total annual $\mathrm{CO}_{2}$ emissions solution heavily relies on the electricity purchased from the electric grid. On the other hand, there is virtually no consumption of natural gas. Consequently, the economic cost and $\mathrm{CO}_{2}$ emissions associated with the annual operation of the system are almost entirely due to the purchase of electricity from the grid. There are, however, hours in which the electricity produced is sold to the electric grid. In fact, $8.7 \%$ of the electricity produced by the system is sold to the grid, generating $1505.1 € / \mathrm{yr}$ of economic profits and displacing 1521.3 $\mathrm{kgCO}_{2} / \mathrm{yr}$ of emissions associated with the electricity available in the electric grid.

Analyzing the annual operation of the system, the PV, ST, and TSQ operate all year round; the HP also operates throughout the year, except for the month of May; the ABS operates all summer, except for September; and the GB operates only in June to cover 
heat peak demands. It should be noted that solar heat $Q_{s t}$ must be dissipated in May (33.1\% of the heat produced by the ST in the month). About a fourth of the electricity consumed (system's internal consumption and electricity demand) is produced by the PV, the rest being covered by the electric grid. Virtually all the heat is produced by the HP (76.2\%) and the ST (23.8\%); the GB has a negligible share. Regarding the cooling production, the HP accounts for $87.9 \%$, all the rest being covered by the ABS driven by solar heat $Q_{s t r}$.

The annual energy flows were obtained by consolidating the hourly energy flows of the representative days. Two examples are provided. Figure 8 shows the hourly electricity and heat productions in January, and Figure 9 presents the hourly electricity, heating, and cooling productions in July.

In January, only electricity $E_{d}$ and heating $Q_{d}$ are required by the consumer center. The system must purchase electricity $E_{p}$ from the grid throughout the day. The PV electricity production $W_{p v}$ peaks at hours 12 and 13. As can be seen, heating is produced and stored at several hours of the day (hours 4, 5, 13 to 17, and 24). The reason for this operation strategy is derived from the hourly $\mathrm{CO}_{2}$ emissions associated with the electricity available in the electric grid, as depicted in Figure 3. In fact, these hours are the ones with the lowest $\mathrm{CO}_{2}$ emissions, so the system takes advantage of its storage capacity to produce heating with lower related environmental impacts. The TSQ is discharged $Q_{\text {out }}$ at hours 7 to 9 and 18 to 20 , when the electricity-related $\mathrm{CO}_{2}$ emissions are the highest. Regarding the solar heating production $Q_{s t x}$, it peaks at hour 13 .

Now, in July, cooling $R_{d}$ is also required, apart from the $E_{d}$ and $Q_{d}$. The PV electricity production $W_{p v}$ is considerably higher than in January, which enables the system to sell electricity to the electric grid from hour 8 to 11 . Likewise, the solar heat produced by the ST is enough so that it can cover the whole daily heating demand (instantaneously and through the storage in the TSQ), as well as a part of the cooling demand through the ABS. Regarding the cooling production, the HP provides most of the cooling required. The ABS at hours 13 to 16 displaces HP production, thus reducing the amount of electricity purchased from the grid and, consequently, the corresponding $\mathrm{CO}_{2}$ emissions.

\subsection{Discussion}

The following points were drawn from the analysis of the single-objective solutions obtained:

- The optimal economic cost solution included the cogeneration module GE, but not the renewable energy technologies (PV and ST), while the optimal environmental solution included both the PV and ST, but not the GE. In fact, the installation of PV and ST occupied all the available rooftop area, reaching the upper constraint of maximum installable capacity;

- The optimal environmental solution, compared with the optimal economic cost solution, presented a higher installed capacity of HP and lower installed capacities of $\mathrm{GB}$ and $\mathrm{ABS}$, which suggests that, for the conditions considered herein, 
electricity-based heating and cooling production is a more environmentally sound alternative to natural gas;

- Also, there was a significant shift in the use of thermal energy storage not only in type but also in quantity (from $39.9 \mathrm{kWh}$ of TSR in the optimal annual cost solution to $314.0 \mathrm{kWh}$ of TSQ in the optimal environmental solution);

- Regarding the consumption of energy resources, both solutions were highly dependent on the electricity from the electric grid. Nevertheless, the optimal economic cost solution was also significantly dependent on the purchase of natural gas. Even though a small quantity, the optimal environmental solution was able to sell electricity to the grid, thus generating economic profit and avoiding $\mathrm{CO}_{2}$ emissions relative to the purchase of electricity from the grid;

- In both economic and environmental optimal solutions, the systems took advantage of time-varying electricity prices and $\mathrm{CO}_{2}$ emissions to achieve lower operating costs and lower environmental impacts; these effects mostly took place in the HP either producing heating or cooling;

- The optimal environmental solution was 52\% less carbon intensive than the optimal economic cost solution, with a $31 \%$ higher total annual cost. Regarding only the manufacturing and installation of technologies, shifting to the more environmentally sound solution increased the annual fixed cost by $183 \%$ and the annual $\mathrm{CO}_{2}$ emissions by $354 \%$. On the other hand, such increased investment costs are offset by a better energy use throughout the operation of the system. As can be seen, there was a decrease of $29 \%$ in the annual operation costs and of $59 \%$ in the annual $\mathrm{CO}_{2}$ emissions associated with the system operation.

- While annual fixed $\mathrm{CO}_{2}$ emissions in the optimal annual cost solution represent only $1.8 \%$ of the total annual emissions, they are more significant in the optimal environmental solution (17.1\%).

\section{Multi-objective optimization}

There are several methods in the literature to solve multi-objective optimization problems. Generally, the approach consists of converting the multi-objective optimization into a series of single-objective optimization problems. An important matter at this stage is the decision-maker's role in the procedure ${ }^{71}$. In this regard, a posteriori approaches, which include the $\varepsilon$-constraint method, have been extensively applied in energy systems optimization studies ${ }^{31,72-75}$. In the $\varepsilon$-constraint method, the problem is optimized with respect to one of the objective functions, while upper and lower limits ( $\varepsilon$-constraints) are established for the others. The interval between the limits is divided and the procedure is repeated for different values of $\varepsilon$, so that each new solution becomes a point in the Pareto set.

In the present analysis, the objective function was the total annual cost, while the environmental objective function was converted into an inequality constraint, thus imposing an upper limit to the total annual $\mathrm{CO}_{2}$ emissions of the system. The single- 
objective solutions described in Section 5 constitute the upper and lower limits of the Pareto set: $155.1 \mathrm{tCO}_{2} / \mathrm{yr}$ (relative to the optimal annual cost solution $\mathrm{B}$ ) and $74.2 \mathrm{tCO}_{2} / \mathrm{yr}$ (relative to the optimal environmental solution A), respectively. The results are shown in Table 6. This information is also depicted Figure 10, using the same tick marks to indicate the same set of technologies.

The analysis of the trade-off solutions that constitute the Pareto set shows that each candidate technology was included in at least one solution; on the other hand, there was no solution that simultaneously included the eight candidate technologies. The GB and the HP were included in all solutions obtained, and the TSR was present in most of them. It is worth noticing that the GE was not included in any solution together with the PV and/or ST.

Reducing the $\mathrm{CO}_{2}$ emissions in the optimal economic cost solution promoted a shift in which the installed capacity of the GB decreased while the installed capacity of the HP increased. The GE was only included at $\mathrm{CO}_{2}$ emissions levels higher than $125.0 \mathrm{tCO}_{2} / \mathrm{yr}$ and even so with relatively small capacities. For total annual $\mathrm{CO}_{2}$ emissions lower than $99.0 \mathrm{tCO}_{2} / \mathrm{yr}$, PV began to be incorporated; its installed capacity increased until the maximum installable capacity corresponding to the available rooftop area was reached at $84.0 \mathrm{tCO}_{2} / \mathrm{yr}$. The rooftop area remained fully occupied from here on. By reducing $\mathrm{CO}_{2}$ emissions from $83.0 \mathrm{tCO}_{2} / \mathrm{yr}$, then $\mathrm{PV}$ gave way to ST, which increased until the environmental optimal (A) was reached. TSQ closely followed the ST, being incorporated for lower values than $82.3 \mathrm{tCO}_{2} / \mathrm{yr}$.

There were two different ranges in which the ABS was included: for $\mathrm{CO}_{2}$ emissions levels higher than $100.0 \mathrm{tCO}_{2} / \mathrm{yr}$ and lower than $81.0 \mathrm{tCO}_{2} / \mathrm{yr}$. It is interesting to look into the role that the ABS played in each scenario: at the higher $\mathrm{CO}_{2}$ emissions range, the ABS was driven exclusively with heat produced with natural gas (GE cogenerated heat, $Q_{c r}$, and mostly GB conventional heat, $Q_{a r}$ ); on the other hand, at the lower range, the ABS was driven exclusively with heat from the ST collectors, $Q_{s t r}$.

The analysis of the trade-off solutions obtained also allowed for the identification of more interesting trade-off solutions than others, such as solutions C and D, in Table 6 and Figure 10. The results are gathered in Table 7.

The preferred trade-off solution (C) was selected because of its reasonable compromise between both objective functions: it achieved a 32.3\% reduction in $\mathrm{CO}_{2}$ emissions with an increase of only $1.1 \%$ in the total annual cost relative to the optimal cost configuration (B). Moreover, solution C included only GB, HP, ABS, and TSR, thus constituting a simpler configuration than solutions $\mathrm{A}$ and $\mathrm{B}$, that should be simpler and cheaper to operate and to maintain. Relative to the optimal cost solution (B), the GB and ABS had their capacities reduced, while the HP saw an increase in its installed capacity. As a result, the system consumed $75.7 \%$ less natural gas and purchases $31.4 \%$ more electricity from the electric grid.

Solution D represents a higher commitment towards a more environmentally friendly solution: it achieved a $45.2 \%$ decrease in $\mathrm{CO}_{2}$ emissions with an increase of $7.3 \%$ in the 
total annual cost relative to the optimal cost configuration (B). This solution included GB, HP, PV, and TSR.

Table 6 also presents the marginal and the average costs of each solution, in $€ / \mathrm{tCO}_{2}$. The marginal cost represents the economic cost of moving from one solution to the next in the Pareto set, while the average cost represents the cost of moving from the optimal cost solution (B) to any other in the set. Thus, these indices constitute a metric for quantifying the designer's effort in the shift from a more polluting energy system to a more sustainable one.

As can be seen from Table 6, it is no surprise that both the marginal and the average costs increase as the solutions shift towards lower $\mathrm{CO}_{2}$ emissions levels. Moving from one optimum to the other (from B to A) would involve an average cost of $402.9 € / \mathrm{tCO}_{2}$. However, taking the trade-off solution $\mathrm{C}$ into account, the average cost of moving from $\mathrm{B}$ to $\mathrm{C}$ is only $24.0 € / \mathrm{tCO}_{2}$.

Based on the different conditions under which the system operates (e.g. climatic data, energy prices, local policies), local subsidies for $\mathrm{CO}_{2}$ emissions savings and/or stock market prices for the $\mathrm{CO}_{2}$ emissions could serve as indices to select among the various trade-off solutions based on their marginal costs. For example:

- The European Emission Allowances ${ }^{76}$ value on August 4, 2018, was about 17.6 $€ / \mathrm{tCO}_{2}$. Taking this value as reference, based on the marginal costs presented in Table 6 it would be possible to achieve a solution that is halfway between the optimal cost $\mathrm{B}$ and the trade-off $\mathrm{C}$;

- An article published in the The Economist ${ }^{77}$ discusses a novel $\mathrm{CO}_{2}$ removal system with a capture cost of about $100 € / \mathrm{tCO}_{2}$. Taking this value as reference and comparing it to the marginal costs presented in Table 6 , it would be possible to achieve a solution that is slightly better than the trade-off $\mathrm{C}$.

It becomes clear that ensuring a higher economic compensation for $\mathrm{CO}_{2}$ emissions savings would enable other trade-off solutions to be chosen, thus stimulating clean technology development and market innovation.

\section{Sensitivity analyses}

In this section sensitivity analyses are carried out to investigate the influence of key parameters on the single-objective and trade-off solutions obtained in Sections 5 and 6, thus contributing to a more well-informed decision-making process. Particularly interesting for this case study are the analyses of energy resources prices (in this case, the purchase price of natural gas), investment costs (in this case, the photovoltaic panels' investment cost), and total rooftop area.

Among the energy resources prices, the purchase price of natural gas $c_{g}$ was analyzed. Table 8 presents the economic optimal solutions obtained for values of $c_{g}$ between 0.045 and $0.065 € / \mathrm{kWh}$. As can be seen, increasing the natural gas price resulted in higher total 
annual costs. Regarding the system configuration, the installed capacities of cogeneration module GE, gas boiler GB and absorption chiller ABS decreased, giving way to the reversible heat pump HP. In fact, GE was no longer installed with $c_{g}=0.065 € / \mathrm{kWh}$. While this reduced the annual fixed cost, it increased the annual operation cost, as energy resources consumption was shifted from natural gas to purchased electricity. From the environmental viewpoint, increasing the natural gas price promoted a significant reduction in total annual $\mathrm{CO}_{2}$ emissions, led almost entirely by the annual operation $\mathrm{CO}_{2}$ emissions.

The Pareto sets obtained for the different $c_{g}$ values are depicted in Figure 11. It was observed that the higher the $c_{g}$ the lower the potential for $\mathrm{CO}_{2}$ emissions reduction from the economic optimal to other trade-off solutions along the Pareto set. Besides, the influence of $c_{g}$ expectedly became less and less important at lower levels of total annual $\mathrm{CO}_{2}$ emissions, as can be seen by the converging curves.

Among the technologies' investment costs, the photovoltaic panels' bare module cost $C I(P V)$ was selected. As shown in Table 9, in the economic optimal solution with $C I(P V)$ $=209 € / \mathrm{m}^{2}$, PV were economically feasible and the model maximized their installation $\left(P I N(P V)=640 \mathrm{~m}^{2}\right)$ by covering all $2000 \mathrm{~m}^{2}$ rooftop area available. Apart from the PV, however, the installed technologies and their capacities remained the same. The increased annual fixed cost was counterbalanced by the lower annual operation cost, since the system not only purchased less electricity from the grid but also sold, so that the total annual cost remained practically unchanged. By contrast, from the environmental viewpoint, the higher annual fixed $\mathrm{CO}_{2}$ emissions were more than compensated by the lower annual operation $\mathrm{CO}_{2}$ emissions, resulting in a reduction of $11 \%$ in the total annual $\mathrm{CO}_{2}$ emissions.

Reducing the $C I(P V)$ further only decreased the annual fixed cost component in the total annual cost, as PV became cheaper. The system configuration and operation, as well as the associated $\mathrm{CO}_{2}$ emissions, remained the same.

Lastly, the influence of the total rooftop area $A A$ was analyzed. Figure 12 shows the Pareto sets obtained for $A A$ values between 500 and $3000 \mathrm{~m}^{2}$. Clearly, this parameter only affected those solutions in which all $A A$ was occupied by photovoltaic panels PV and solar thermal collectors ST, such as the environmental optimal solution A, as indicated by the converging curves for total annual $\mathrm{CO}_{2}$ emissions higher than $95 \mathrm{tCO}_{2} / \mathrm{yr}$.

In the environmental optimal solution, increasing the $A A$ expectedly reduced the total annual $\mathrm{CO}_{2}$ emissions, since more PV and ST could be installed. The shares of PV and ST installed are shown in Figure 13. As $A A$ increased, ST were the first to be installed, up to $P I N(S T)=246 \mathrm{~m}^{2}$ (or $559 \mathrm{~m}^{2}$ of total rooftop area), from which point onwards installation of PV followed. This indicated that while ST were preferred over PV to reduce $\mathrm{CO}_{2}$ emissions, there was a saturation of the solar heat that the system could effectively consume. Apart from PV and ST, the other technologies' installed capacities remained the same. 


\section{Conclusions}

This paper proposed a multi-period multi-objective optimization model formulated with MILP that determines the optimal configuration and operational strategy of a trigeneration system including RETs and TES. The objective functions were the minimum total annual cost and the minimum total annual $\mathrm{CO}_{2}$ emissions, both of which consisted of a fixed term, relative to the manufacturing and installation of the technologies, and a variable term, relative to the hourly operation of the system. The model carefully represented the dynamic conditions that govern the selection of technologies and the hour by hour operation of the system, which ultimately affect the objective function. Therefore, the results obtained were specific for the analyzed case study.

The MILP model was applied to a multi-family building complex in Zaragoza, Spain. The single-objective solutions presented fundamentally different configurations as regards the installation of the cogeneration module (included in the economic optimal solution) and RETs (included in the environmental optimal solution). By generating the Pareto curve, it was possible to identify promising intermediate trade-off solutions with reasonable compromises between the economic and the environmental criteria. For instance, imposing $\mathrm{CO}_{2}$ emissions restrictions displaced cogeneration in favor of the reversible heat pump, photovoltaic panels, and the electric grid, reaching a trade-off solution that reduced $\mathrm{CO}_{2}$ emissions by $45.2 \%$ with a moderate increase of $7.3 \%$ in the total annual cost.

The approach proposed in this study was intended as a pre-design procedure. Thus, future work could extend the synthesis model to the design stage so that, once the technologies to be installed have been selected and the part of the model that describes their performances has been refined, the optimization model can determine the number of devices and their corresponding installed capacities. As a result, this would enable the model to incorporate a dispatch schedule that takes into account the effect of devices' partial load operation and start-up/ramp/shutdown on the system's performance.

\section{Acknowledgements}

This work was developed in the frame of the research project ENE2017-87711-R, partially funded by the Spanish Government (Energy Program), the Government of Aragon (Ref: T55-17R), Spain, and the EU Social Fund (FEDER Program 2014-2020 "Building Europe from Aragon"). Eduardo Pina acknowledges financial support from the Brazilian Federal Government/CNPq.

\section{References}

1. IEA. Energy Technology Perspectives 2017 - Executive Summary.; 2017. http://www.iea.org/publications/freepublications/publication/EnergyTechnologyP erspectives2017ExecutiveSummaryEnglishversion.pdf. 
2. European Parliament. Directive 2010/31/EU of the European Parliament and of the Council of 19 May 2010 on the energy performance of buildings (recast). Off J Eur Union. 2010:13-35.

3. Parliament E. Directive 2018/844 of the European Parliament and of the Council of 30 May 2018 amending Directive 2010/31/EU on the energy performance of buildings and Directive 2012/27/EU on energy efficiency. Off J Eur Union. 2018;156:75-91. content/ES/TXT/?uri=CELEX:32018L0844.

https://eur-lex.europa.eu/legal-

4. Petchers N. Combined Heating, Cooling \& Power Handbook: Technologies \& Applications. Marcel Dekker; 2003.

5. Murugan S, Horák B. A review of micro combined heat and power systems for residential applications. Renew Sustain Energy Rev. 2016;64:144-162. doi:10.1016/j.rser.2016.04.064

6. Jradi M, Riffat S. Tri-generation systems: Energy policies, prime movers, cooling technologies, configurations and operation strategies. Renew Sustain Energy Rev. 2014;32:396-415. doi:10.1016/j.rser.2014.01.039

7. Wu DW, Wang RZ. Combined cooling, heating and power: A review. Prog Energy Combust Sci. 2006;32(5-6):459-495. doi:10.1016/j.pecs.2006.02.001

8. Liu M, Shi Y, Fang F. Combined cooling, heating and power systems: A survey. Renew Sustain Energy Rev. 2014;35:1-22. doi:10.1016/j.rser.2014.03.054

9. Chicco G, Mancarella P. Distributed multi-generation: A comprehensive view. Renew Sustain Energy Rev. 2009;13(3):535-551. doi:10.1016/j.rser.2007.11.014

10. Jana K, Ray A, Majoumerd MM, Assadi M, De S. Polygeneration as a future sustainable energy solution - A comprehensive review. Appl Energy. 2017;202:88-111. doi:10.1016/j.apenergy.2017.05.129

11. Modi A, Bühler F, Andreasen JG, Haglind F. A review of solar energy based heat and power generation systems. Renew Sustain Energy Rev. 2017;67:1047-1064. doi:10.1016/j.rser.2016.09.075

12. Arteconi A, Hewitt NJ, Polonara F. State of the art of thermal storage for demandside management. Appl Energy. 2012;93:371-389. doi:10.1016/j.apenergy.2011.12.045

13. Steen D, Stadler M, Cardoso G, Groissböck M, DeForest N, Marnay C. Modeling of thermal storage systems in MILP distributed energy resource models. Appl Energy. 2015;137:782-792. doi:10.1016/j.apenergy.2014.07.036

14. Bruno JC, Fernandez F, Castells F, Grossmann IE. A rigorous MINLP model for the optimal synthesis and operation of utility plants. Chem Eng Res Des. 1998;76(March):246-258. doi:10.1205/026387698524901

15. Pina EA, Lozano MA, Serra LM. Thermoeconomic cost allocation in simple trigeneration systems including thermal energy storage. Energy. 2018;153. doi:10.1016/j.energy.2018.04.012

16. Rong A, Su Y. Polygeneration systems in buildings: A survey on optimization approaches. Energy Build. 2017;151:439-454. doi:10.1016/j.enbuild.2017.06.077 
17. Liu P, Georgiadis MC, Pistikopoulos EN. An energy systems engineering approach for the design and operation of microgrids in residential applications. Chem Eng Res Des. 2013;91(10):2054-2069. doi:10.1016/j.cherd.2013.08.016

18. Azapagic A. Assessing Environmental Sustainability: Life Cycle Thinking and Life Cycle Assessment. In: Sustainable Development in Practice. Chichester, UK: John Wiley \& Sons, Ltd; 2010:56-80. doi:10.1002/9780470972847.ch3

19. $\mathrm{Ng} \mathrm{KS}$, Martinez Hernandez E. A systematic framework for energetic, environmental and economic (3E) assessment and design of polygeneration systems. Chem Eng Res Des. 2016;106(January 2016):1-25. doi:10.1016/j.cherd.2015.11.017

20. Andiappan V. State-Of-The-Art Review of Mathematical Optimisation Approaches for Synthesis of Energy Systems. Process Integr Optim Sustain. 2017;1(3):165-188. doi:10.1007/s41660-017-0013-2

21. Akbari K, Nasiri MM, Jolai F, Ghaderi SF. Optimal investment and unit sizing of distributed energy systems under uncertainty: A robust optimization approach. Energy Build. 2014;85:275-286. doi:10.1016/j.enbuild.2014.09.009

22. Mehleri ED, Sarimveis H, Markatos NC, Papageorgiou LG. A mathematical programming approach for optimal design of distributed energy systems at the neighbourhood level. Energy. 2012;44(1):96-104. doi:10.1016/j.energy.2012.02.009

23. Ren H, Gao W. A MILP model for integrated plan and evaluation of distributed energy systems. Appl Energy. 2010;87(3):1001-1014. doi:10.1016/j.apenergy.2009.09.023

24. Thiem S, Danov V, Metzger M, Schäfer J, Hamacher T. Project-level multi-modal energy system design - Novel approach for considering detailed component models and example case study for airports. Energy. 2017;133:691-709. doi:10.1016/j.energy.2017.05.159

25. Ma T, Wu J, Hao L. Energy flow modeling and optimal operation analysis of the micro energy grid based on energy hub. Energy Convers Manag. 2017;133:292306. doi:10.1016/j.enconman.2016.12.011

26. Sanaye S, Sarrafi A. Optimization of combined cooling, heating and power generation by a solar system. Renew Energy. 2015;80:699-712. doi:10.1016/j.renene.2015.02.043

27. Ameri M, Besharati Z. Optimal design and operation of district heating and cooling networks with CCHP systems in a residential complex. Energy Build. 2016;110:135-148. doi:10.1016/j.enbuild.2015.10.050

28. Ashouri A, Fux SS, Benz MJ, Guzzella L. Optimal design and operation of building services using mixed-integer linear programming techniques. Energy. 2013;59:365-376. doi:10.1016/j.energy.2013.06.053

29. Wang J, Yang Y, Mao T, Sui J, Jin H. Life cycle assessment (LCA) optimization of solar-assisted hybrid CCHP system. Appl Energy. 2015;146:38-52. doi:10.1016/j.apenergy.2015.02.056

30. González A, Riba J-R, Rius A. Combined heat and power design based on 
environmental and cost criteria. Energy. 2016;116:922-932. doi:10.1016/j.energy.2016.10.025

31. Carvalho M, Lozano MA, Serra LM. Multicriteria synthesis of trigeneration systems considering economic and environmental aspects. Appl Energy. 2012;91(1):245-254. doi:10.1016/j.apenergy.2011.09.029

32. Nagapurkar P, Smith JD. Techno-economic optimization and environmental Life Cycle Assessment (LCA) of microgrids located in the US using genetic algorithm. Energy Convers Manag. 2019;181(September 2018):272-291. doi:10.1016/j.enconman.2018.11.072

33. Voorspools KR, D'haeseleer WD. The impact of the implementation of cogeneration in a given energetic context. IEEE Trans Energy Convers. 2003;18(1):135-141. doi:10.1109/TEC.2002.808332

34. Haeseldonckx D, Peeters L, Helsen L, D'haeseleer W. The impact of thermal storage on the operational behaviour of residential CHP facilities and the overall CO2 emissions. Renew Sustain Energy Rev. 2007;11(6):1227-1243. doi:10.1016/j.rser.2005.09.004

35. Messagie M, Mertens J, Oliveira L, et al. The hourly life cycle carbon footprint of electricity generation in Belgium, bringing a temporal resolution in life cycle assessment. Appl Energy. 2014;134:469-476. doi:10.1016/j.apenergy.2014.08.071

36. Gordon C, Fung A. Hourly emission factors From the electricity generation sector - A tool for analyzing the impact of renewable technologies In ontario. Trans Can Soc Mech Eng. 2009;33(1):105-118. doi:10.1139/tcsme-2009-0010

37. Kopsakangas-Savolainen M, Mattinen MK, Manninen K, Nissinen A. Hourlybased greenhouse gas emissions of electricity - cases demonstrating possibilities for households and companies to decrease their emissions. J Clean Prod. 2017;153:384-396. doi:10.1016/j.jclepro.2015.11.027

38. Khan I, Jack MW, Stephenson J. Analysis of greenhouse gas emissions in electricity systems using time-varying carbon intensity. J Clean Prod. 2018;184:1091-1101. doi:10.1016/j.jclepro.2018.02.309

39. Kelley MT, Baldick R, Baldea M. Demand Response Operation of ElectricityIntensive Chemical Processes for Reduced Greenhouse Gas Emissions: Application to an Air Separation Unit. ACS Sustain Chem Eng. 2019;7(2):19091922. doi:10.1021/acssuschemeng.8b03927

40. Baumgärtner N, Delorme R, Hennen M, Bardow A. Design of low-carbon utility systems: Exploiting time-dependent grid emissions for climate-friendly demandside management. Appl Energy. 2019;247(May):755-765. doi:10.1016/j.apenergy.2019.04.029

41. Sigarchian SG, Malmquist A, Martin V. Design optimization of a complex polygeneration system for a hospital. Energies. 2018;11(5). doi:10.3390/en11051071

42. Maroufmashat A, Elkamel A, Fowler M, et al. Modeling and optimization of a network of energy hubs to improve economic and emission considerations. Energy. 2015;93:2546-2558. doi:10.1016/j.energy.2015.10.079 
43. Pina EA, Lozano MA, Serra LM. Multicriteria Synthesis of Trigeneration Systems Assisted With Renewable Energy Sources and Thermal Energy Storage. In: Volume 2: I\&C, Digital Controls, and Influence of Human Factors; Plant Construction Issues and Supply Chain Management; Plant Operations, Maintenance, Aging Management, Reliability and Performance; Renewable Energy Systems: Solar, Wind, Hydro and Geotherm. June 26-30, 2017, Charlotte, North Carolina, USA: ASME; 2017:V002T12A001. doi:10.1115/POWERICOPE2017-3103

44. Yan Y, Zhang H, Meng J, et al. Carbon footprint in building distributed energy system: An optimization-based feasibility analysis for potential emission reduction. J Clean Prod. 2019;239:117990. doi:10.1016/j.jclepro.2019.117990

45. D'Agostino D, Parker D, Melià P. Environmental and economic implications of energy efficiency in new residential buildings: A multi-criteria selection approach. Energy Strateg Rev. 2019;26(August):100412. doi:10.1016/j.esr.2019.100412

46. Karmellos M, Mavrotas G. Multi-objective optimization and comparison framework for the design of Distributed Energy Systems. Energy Convers Manag. 2019;180(July 2018):473-495. doi:10.1016/j.enconman.2018.10.083

47. Casisi M, Costanzo S, Pinamonti P, Reini M. Two-Level Evolutionary Multiobjective Optimization of a District Heating System with Distributed Cogeneration. Energies. 2018;12(1):114. doi:10.3390/en12010114

48. Conci M, Konstantinou T, van den Dobbelsteen A, Schneider J. Trade-off between the economic and environmental impact of different decarbonisation strategies for residential buildings. Build Environ. 2019;155(January):137-144. doi:10.1016/j.buildenv.2019.03.051

49. Safaei A, Freire F, Antunes CH. A model for optimal energy planning of a commercial building integrating solar and cogeneration systems. Energy. 2013;61:211-223. doi:10.1016/j.energy.2013.08.048

50. Brandoni C, Renzi M. Optimal sizing of hybrid solar micro-CHP systems for the household sector. Appl Therm Eng. 2015;75:896-907. doi:10.1016/j.applthermaleng.2014.10.023

51. Tan Y, Wang X, Zheng Y. Modeling and daily operation optimization of a distributed energy system considering economic and energy aspects. Int J Energy Res. 2018;42(11):3477-3495. doi:10.1002/er.4070

52. Yokoyama R, Ito K, Kamimura K, Miyasaka F. Development of a GeneralPurpose Optimal Operational Planning System for Energy Supply Plants. J Energy Resour Technol. 1994;116(4):290. doi:10.1115/1.2906456

53. Lozano MA, Ramos JC, Carvalho M, Serra LM. Structure optimization of energy supply systems in tertiary sector buildings. Energy Build. 2009;41(10):1063-1075. doi:10.1016/j.enbuild.2009.05.008

54. Biegler L, Grossmann I. Retrospective on optimization. Comput Chem Eng. 2004;28:1169-1192.

55. Ünal AN, Ercan S, Kayakutlu G. Optimisation studies on tri-generation: A review. Int J Energy Res. 2015;39(10):1311-1334. doi:10.1002/er.3342 
56. Iyer RR, Grossmann IE. Synthesis and operational planning of utility systems for multiperiod operation. Comput Chem Eng. 1998;22(7):979-993. doi:10.1016/S0098-1354(97)00270-6

57. Ondeck A, Edgar TF, Baldea M. A multi-scale framework for simultaneous optimization of the design and operating strategy of residential CHP systems. Appl Energy. 2017;205(May):1495-1511. doi:10.1016/j.apenergy.2017.08.082

58. Pina EA. Thermoeconomic and environmental synthesis and optimization of polygeneration systems supported with renewable energies and thermal energy storage applied to the residential-commercial sector. $\mathrm{PhD}$ Thesis - University of Zaragoza, Department of Mechanical Engineering. 2019.

59. Duffie JA, Beckman WA, Worek WM. Solar Engineering of Thermal Processes. 4th ed. Wiley; 2013. doi:10.1115/1.2930068

60. Pina EA, Lozano MA, Serra LM. Thermoeconomic Analysis of Cogeneration Systems Assisted with Solar Thermal Heat and Photovoltaics. In: Proceedings of EuroSun2016. Freiburg, Germany: International Solar Energy Society; 2016:1-12. doi:10.18086/eurosun.2016.05.03

61. Guadalfajara M, Lozano MA, Serra LM. Simple calculation tool for central solar heating plants with seasonal storage. Sol Energy. 2015;120:72-86. doi:10.1016/j.solener.2015.06.011

62. Erbs DG, Beckman WA, Klein SA. Estimation of degree-days and ambient temperature bin data from monthly-average temperatures. ASHRAE J. 1983;25:6(June):60-65.

63. AEMET. Guía Resumida del Clima en España 1981-2010. http://www.aemet.es/en/conocermas/recursos_en_linea/publicaciones_y_estudios /publicaciones/detalles/guia_resumida_2010. Published 2010. Accessed August 30, 2016.

64. EDP. Gas and Electricity Prices - Liberalized Market. Gas and Electricity Prices Liberalized Market. http://www.edpenergia.es/es/hogares/gas-yelectricidad/precios/mercado-libre/. Published 2017. Accessed August 31, 2017.

65. Carvalho M. Thermoeconomic and environmental analyses for the synthesis of polygeneration systems in the residential-commercial sector. $\mathrm{PhD}$ Thesis University of Zaragoza, Department of Mechanical Engineering. 2011. http://zaguan.unizar.es/record/5744/files/TESIS-2011-025.pdf.

66. Guadalfajara M. Economic and environmental analysis of central solar heating plants with seasonal storage for the residential sector. PhD Thesis - University of Zaragoza, Department of Mechanical Engineering. 2016. https://zaguan.unizar.es/record/56714/files/TESIS-2016-196.pdf.

67. Ito M, Komoto K, Kurokawa K. A comparative LCA study on potential of verylarge scale PV systems in Gobi desert. Conf Rec IEEE Photovolt Spec Conf. 2009:000729-000732. doi:10.1109/PVSC.2009.5411180

68. IDAE. Factores de emisión de $\mathrm{CO}_{2}$ y coeficientes de paso a energía primaria de diferentes fuentes de energía final consumidas en el sector de edificios en España (in Spanish). 2014:31. 
69. REE. Real-time demand and generation. Red Eléctrica de España - Spanish Peninsula, Electricity demand tracking in real time. http://www.ree.es/en/activities/realtime-demand-and-generation. Published 2018. Accessed May 25, 2018.

70. Schrage L. Optimization modeling with LINGO. Lindo Syst. 1999.

71. Jing R, Wang M, Zhang Z, et al. Comparative study of posteriori decision-making methods when designing building integrated energy systems with multi-objectives. Energy Build. 2019;194:123-139. doi:10.1016/j.enbuild.2019.04.023

72. Alarcon-Rodriguez A, Ault G, Galloway S. Multi-objective planning of distributed energy resources: A review of the state-of-the-art. Renew Sustain Energy Rev. 2010;14(5):1353-1366. doi:10.1016/j.rser.2010.01.006

73. Fazlollahi S, Mandel P, Becker G, Maréchal F. Methods for multi-objective investment and operating optimization of complex energy systems. Energy. 2012;45(1):12-22. doi:10.1016/j.energy.2012.02.046

74. Gebreslassie BH, Guillén-Gosálbez G, Jiménez L, Boer D. Solar assisted absorption cooling cycles for reduction of global warming: A multi-objective optimization approach. Sol Energy. 2012;86(7):2083-2094. doi:10.1016/j.solener.2012.04.010

75. Buoro D, Casisi M, De Nardi A, Pinamonti P, Reini M. Multicriteria optimization of a distributed energy supply system for an industrial area. Energy. 2013;58:128137. doi:10.1016/j.energy.2012.12.003

76. EEX. European Emissions Allowances. https://www.eex.com/en/marketdata/environmental-markets/spot-market/european-emission-

allowances\#!/2018/08/03. Published 2018. Accessed August 4, 2018.

77. The Economist. Extracting carbon dioxide from the air is possible. But at what cost? The Economist. https://www.economist.com/science-andtechnology/2018/06/07/extracting-carbon-dioxide-from-the-air-is-possible.-butat-whatcost?fsrc=scn/tw/te/bl/ed/extractingcarbondioxidefromtheairispossiblebutatwhatc ostclimatechange. Published 2018. Accessed August 4, 2018. 
Table 1: Energy demands of the consumer center per representative day.

\begin{tabular}{|c|c|c|c|c|c|c|c|}
\hline \multirow{2}{*}{$\begin{array}{c}\text { Representative } \\
\text { day } \\
d\end{array}$} & \multirow{2}{*}{$\begin{array}{l}\text { Number of } \\
\text { representative } \\
\text { days type } d \\
\text { per year } \\
N R Y(d)\end{array}$} & \multicolumn{2}{|c|}{$\begin{array}{l}\text { Heating } \\
\text { Demand }\end{array}$} & \multicolumn{2}{|c|}{$\begin{array}{l}\text { Electricity } \\
\text { demand }\end{array}$} & \multicolumn{2}{|c|}{$\begin{array}{l}\text { Cooling } \\
\text { demand }\end{array}$} \\
\hline & & $\begin{array}{c}\text { Total, } \\
\text { kWh/day }\end{array}$ & $\begin{array}{c}\text { Mean, } \\
\text { kW }\end{array}$ & $\begin{array}{c}\text { Total, } \\
\text { kWh/day }\end{array}$ & $\begin{array}{c}\text { Mean, } \\
\text { kW }\end{array}$ & $\begin{array}{c}\text { Total, } \\
\text { kWh/day }\end{array}$ & $\begin{array}{c}\text { Mean, } \\
\text { kW }\end{array}$ \\
\hline Jan & 31 & 4061.80 & 169.24 & 776.10 & 32.34 & 0.00 & 0.00 \\
\hline Feb & 28 & 3366.70 & 140.28 & 776.00 & 32.33 & 0.00 & 0.00 \\
\hline Mar & 31 & 1916.80 & 79.87 & 776.10 & 32.34 & 0.00 & 0.00 \\
\hline Apr & 30 & 1065.90 & 44.41 & 694.30 & 28.93 & 0.00 & 0.00 \\
\hline May & 31 & 456.80 & 19.03 & 694.00 & 28.92 & 0.00 & 0.00 \\
\hline Jun & 30 & 424.00 & 17.67 & 626.00 & 26.08 & 559.90 & 23.33 \\
\hline Jul & 31 & 351.50 & 14.65 & 626.00 & 26.08 & 1538.50 & 64.10 \\
\hline Aug & 31 & 312.40 & 13.02 & 626.00 & 26.08 & 1144.30 & 47.68 \\
\hline Sep & 30 & 382.10 & 15.92 & 626.00 & 26.08 & 467.50 & 19.48 \\
\hline Oct & 31 & 422.40 & 17.60 & 694.00 & 28.92 & 0.00 & 0.00 \\
\hline Nov & 30 & 2327.80 & 96.99 & 694.30 & 28.93 & 0.00 & 0.00 \\
\hline Dec & 31 & 3873.20 & 161.38 & 776.10 & 32.34 & 0.00 & 0.00 \\
\hline Jan-X & 0 & 4874.00 & 203.00 & 931.00 & 39.00 & 0.00 & 0.00 \\
\hline Jul-x & 0 & 422.00 & 18.00 & 751.00 & 31.00 & 1846.00 & 77.00 \\
\hline
\end{tabular}


Table 2: Main technical parameters of the technologies in the superstructure.

\begin{tabular}{|c|c|c|c|}
\hline $\begin{array}{c}\text { Technology } \\
t\end{array}$ & $\begin{array}{l}\text { Model and } \\
\text { manufacturer }\end{array}$ & Parameter & Value \\
\hline \multirow{2}{*}{ GE } & \multirow{2}{*}{$\begin{array}{l}\text { Dachs, } \\
\text { Senertec }\end{array}$} & $\alpha_{w}$ : Electric power efficiency & 0.26 \\
\hline & & $\alpha_{q}:$ Thermal efficiency & 0.61 \\
\hline GB & $\begin{array}{l}\text { CPA-BTH } \\
100, \text { Baxi }\end{array}$ & $\eta_{q}:$ Thermal efficiency & 0.95 \\
\hline \multirow{3}{*}{$\mathrm{HP}$} & \multirow{3}{*}{$\begin{array}{l}\text { RLA HE, } \\
\text { Ferroli }\end{array}$} & COPhpq: COP (heating mode) & 3.24 \\
\hline & & EERhpr: EER (cooling mode) & 3.19 \\
\hline & & RCAPrq: Cooling/heating capacity ratio & 0.90 \\
\hline \multirow[b]{2}{*}{$\mathrm{ABS}$} & \multirow[b]{2}{*}{$\begin{array}{l}\text { Cogenie, } \\
\text { Thermax }\end{array}$} & COPabs: COP & 0.69 \\
\hline & & $\begin{array}{l}\text { kwabs: Unit auxiliary electricity } \\
\text { consumption }\end{array}$ & 0.03 \\
\hline TSQ & Idrogas & fpacuQ: Hourly energy loss factor & $0.01 \mathrm{~h}^{-1}$ \\
\hline TSR & Idrogas & fpacuR: Hourly energy loss factor & $0.01 \mathrm{~h}^{-1}$ \\
\hline \multirow{10}{*}{ PV } & \multirow{10}{*}{$\begin{array}{l}\text { SW } 260 \text { Poly, } \\
\text { SolarWorld }\end{array}$} & $r p v:$ Rooftop area usage & $\begin{array}{r}3.1250 \mathrm{~m}^{2} \\
\mathrm{roof} / \mathrm{m}^{2}\end{array}$ \\
\hline & & $A_{p v}:$ Module surface area & $1.67 \mathrm{~m}^{2}$ \\
\hline & & $P_{p v}:$ Maximum power & $0.26 \mathrm{~kW}$ \\
\hline & & $\eta_{p v}:$ Module efficiency & 0.1551 \\
\hline & & $\mu_{T}:$ Temperature coefficient of power & $0.0041^{\circ} \mathrm{C}^{-1}$ \\
\hline & & $Q_{r, S R C}:$ Irradiation at SRC conditions & $1.00 \mathrm{~kW} / \mathrm{m}^{2}$ \\
\hline & & $T_{c, S R C}:$ Cell temperature at SRC conditions & $25^{\circ} \mathrm{C}$ \\
\hline & & $Q_{r, \text { NOCT: }}$ Irradiation at NOCT conditions & $0.80 \mathrm{~kW} / \mathrm{m}^{2}$ \\
\hline & & $\begin{array}{l}T_{c, N O C T: \text { Cell temperature at NOCT }} \\
\text { conditions }\end{array}$ & $47^{\circ} \mathrm{C}$ \\
\hline & & $\begin{array}{l}T_{a, N O C T} \text { : Ambient temperature at NOCT } \\
\text { conditions }\end{array}$ & $20^{\circ} \mathrm{C}$ \\
\hline \multirow{5}{*}{ ST } & \multirow{5}{*}{$\begin{array}{l}\text { GK 5000, } \\
\text { Solar Energy }\end{array}$} & $r s t:$ Rooftop area usage & $\begin{array}{r}2.2676 \mathrm{~m}^{2} \\
\mathrm{roof} / \mathrm{m}^{2}\end{array}$ \\
\hline & & $A_{s t}:$ Module surface area & $5.04 \mathrm{~m}^{2}$ \\
\hline & & $k_{0}$ : Thermal coefficient & 0.789 \\
\hline & & $k_{l}$ : Thermal coefficient & $3.834 \mathrm{~W} /\left(\mathrm{m}^{2} \cdot \mathrm{K}\right)$ \\
\hline & & $k_{2}$ : Thermal coefficient & $\begin{array}{r}0.011 \\
\mathrm{~W} /\left(\mathrm{m}^{2} \cdot \mathrm{K}^{2}\right)\end{array}$ \\
\hline
\end{tabular}


Table 3: Technologies' bare module cost, unit $\mathrm{CO}_{2}$ emissions and maximum installable capacity.

\begin{tabular}{cccc}
\hline $\begin{array}{c}\text { Technology } \\
\boldsymbol{t}\end{array}$ & $\begin{array}{c}\text { Bare module cost } \\
\boldsymbol{C I}\end{array}$ & $\begin{array}{c}\text { Unit } \mathbf{C O}_{2} \text { emissions } \\
\boldsymbol{C O} \boldsymbol{O} \boldsymbol{U}\end{array}$ & $\begin{array}{c}\text { Maximum } \\
\text { installable capacity } \\
\boldsymbol{P I N}_{\boldsymbol{M A X}}\end{array}$ \\
\hline $\mathrm{GE}$ & $2700 € / \mathrm{kW}_{\mathrm{el}}$ & $65 \mathrm{kgCO}_{2} / \mathrm{kW}_{\mathrm{el}}$ & $500 \mathrm{~kW}$ el \\
$\mathrm{GB}$ & $77 € / \mathrm{kW}_{\text {th }}$ & $10 \mathrm{kgCO}_{2} / \mathrm{kW}_{\text {th }}$ & $500 \mathrm{~kW}$ \\
$\mathrm{HP}$ & $481 € / \mathrm{kW}_{\text {th }}$ & $160 \mathrm{kgCO}_{2} / \mathrm{kW}_{\text {th }}$ & $500 \mathrm{~kW}$ \\
$\mathrm{ABS}$ & $518 € / \mathrm{kW}_{\text {th }}$ & $165 \mathrm{kgCO}_{2} / \mathrm{kW}_{\text {th }}$ & $500 \mathrm{~kW}$ \\
$\mathrm{TSQ}$ & $150 € / \mathrm{kWh}$ & $150 \mathrm{kgCO}_{2} / \mathrm{kWh}$ & $1000 \mathrm{kWh}$ \\
$\mathrm{TSR}$ & $300 € / \mathrm{kWh}$ & $300 \mathrm{kgCO}_{2} / \mathrm{kWh}$ & $1000 \mathrm{kWh}$ \\
$\mathrm{PV}$ & $264 € / \mathrm{m}^{2}$ panel & $285 \mathrm{kgCO}_{2} / \mathrm{m}^{2}$ panel & $A A=2000 \mathrm{~m}^{2}$ \\
$\mathrm{ST}$ & $578 € / \mathrm{m}^{2}$ collector & $95 \mathrm{kgCO}_{2} / \mathrm{m}^{2}$ collector & rooftop \\
\hline
\end{tabular}


Table 4: Hourly electricity prices, in $€ / \mathrm{kWh}$

\begin{tabular}{ccccccc}
\hline \multirow{2}{*}{ Annual period } & \multicolumn{2}{c}{ On-peak } & \multicolumn{2}{c}{ Mid-peak } & \multicolumn{2}{c}{ Off-peak } \\
\cline { 2 - 7 } & Hours & $\boldsymbol{c}_{\boldsymbol{e}}$ & Hours & $\boldsymbol{c}_{\boldsymbol{e}}$ & Hours & $\boldsymbol{c}_{\boldsymbol{e}}$ \\
\hline $\begin{array}{c}\text { January-March, November- } \\
\begin{array}{c}\text { December } \\
\text { April-October }\end{array}\end{array}$ & $19-22$ & 0.183 & $9-18,23-24$ & 0.156 & $1-8$ & 0.122 \\
\hline
\end{tabular}


Table 5: Single-objective optimization solutions.

\begin{tabular}{|c|c|c|c|c|c|c|c|c|c|}
\hline \multirow{2}{*}{\multicolumn{2}{|c|}{ Technology }} & \multicolumn{4}{|c|}{ Optimal economic cost solution (B) } & \multicolumn{4}{|c|}{ Optimal environmental solution (A) } \\
\hline & & $\begin{array}{c}\text { Capacity } \\
\text { PIN }\end{array}$ & $\begin{array}{c}\text { Load factor } \\
\qquad f u\end{array}$ & $\begin{array}{c}\text { Investment } \\
€ / \mathbf{y r}\end{array}$ & $\begin{array}{c}\mathrm{CO}_{2} \text { emissions } \\
\mathrm{kgCO}_{2} / \mathrm{yr}\end{array}$ & $\begin{array}{l}\text { Capacity } \\
\text { PIN }\end{array}$ & $\begin{array}{l}\text { Load factor } \\
\qquad f u\end{array}$ & $\begin{array}{c}\text { Investment } \\
€ / \mathbf{y r}\end{array}$ & $\begin{array}{c}\mathrm{CO}_{2} \text { emissions } \\
\mathrm{kgCO}_{2} / \mathrm{yr}\end{array}$ \\
\hline GE & Cogeneration module & $4.2 \mathrm{~kW}_{\mathrm{el}}$ & 0.88 & 2050.8 & 13.7 & $0.0 \mathrm{~kW}_{\mathrm{el}}$ & - & - & - \\
\hline GB & Gas boiler & $204.8 \mathrm{~kW}$ & 0.13 & 2838.1 & 102.4 & $49.3 \mathrm{~kW}$ & 0.00 & 683.1 & 24.6 \\
\hline HP & Heat pump & $162.1 \mathrm{~kW}$ & 0.50 & $14,031.7$ & 1296.5 & $269.6 \mathrm{~kW}$ & 0.40 & $23,343.1$ & 2156.9 \\
\hline ABS & Absorption chiller & $94.0 \mathrm{~kW}$ & 0.02 & 8761.6 & 775.2 & $48.8 \mathrm{~kW}$ & 0.07 & 4554.4 & 403.0 \\
\hline PV & Photovoltaic panels & $0 \mathrm{~m}^{2}$ & - & - & - & $461.2 \mathrm{~m}^{2}$ & 0.17 & $21,873.1$ & 6571.6 \\
\hline ST & Solar thermal collectors & $0 \mathrm{~m}^{2}$ & - & - & - & $246.5 \mathrm{~m}^{2}$ & 0.10 & $25,618.8$ & 1170.7 \\
\hline TSQ & Hot water storage tank & $0.4 \mathrm{kWh}$ & - & 10.8 & 3.0 & $314.0 \mathrm{kWh}$ & - & 8449.1 & 2354.8 \\
\hline TSR & Chilled water storage tank & $39.9 \mathrm{kWh}$ & - & 2148.9 & 598.9 & $0.0 \mathrm{kWh}$ & - & - & - \\
\hline \multicolumn{4}{|c|}{ Annual fixed cost $C T E_{f i x}$ and emissions $C O 2_{f i x}$} & $29,841.9$ & 2789.8 & & & $84,521.6$ & $12,681.6$ \\
\hline & Energy resource & \multicolumn{2}{|c|}{$\begin{array}{c}\text { Consumption } \\
\mathbf{k W h} / \mathbf{y r}\end{array}$} & $\begin{array}{c}\text { Energy cost } \\
€ / \mathbf{y r}\end{array}$ & $\begin{array}{c}\mathrm{CO}_{2} \text { emissions } \\
\mathrm{kgCO}_{2} / \mathrm{yr}\end{array}$ & \multicolumn{2}{|c|}{$\begin{array}{c}\text { Consumption } \\
\mathbf{k W h} / \mathbf{y r}\end{array}$} & $\begin{array}{c}\text { Energy cost } \\
€ / y \mathbf{y r}\end{array}$ & $\begin{array}{c}\mathrm{CO}_{2} \text { emissions } \\
\mathrm{kgCO}_{2} / \mathrm{yr}\end{array}$ \\
\hline & Natural gas & \multicolumn{2}{|c|}{$363,285.1$} & $20,557.7$ & $91,547.8$ & \multicolumn{2}{|c|}{124.2} & 7.0 & 31.3 \\
\hline & Purchased electricity & \multicolumn{2}{|c|}{$355,040.0$} & $54,667.3$ & $60,728.1$ & \multicolumn{2}{|c|}{$355,919.7$} & $54,606.8$ & $63,048.5$ \\
\hline & Sold electricity & \multicolumn{2}{|c|}{0} & - & - & \multicolumn{2}{|c|}{-9348.0} & -1505.1 & -1521.3 \\
\hline \multicolumn{4}{|c|}{ Annual variable cost $C T E_{v a r}$ and emissions $C O 2_{v a r}$} & $75,225.0$ & $152,275.9$ & & & $53,108.7$ & $61,558.5$ \\
\hline \multicolumn{4}{|c|}{ Total annual cost $C T E_{t o t}$ and emissions $C O 2_{t o t}$} & $105,066.9$ & $155,065.7$ & & & $137,630.2$ & $74,240.1$ \\
\hline
\end{tabular}


Table 6: Trade-off solutions between economic cost and $\mathrm{CO}_{2}$ emissions.

\begin{tabular}{|c|c|c|c|c|c|c|c|c|c|c|c|}
\hline \multirow{2}{*}{$\begin{array}{c}\varepsilon \text { (total annual } \\
\mathrm{CO}_{2} \text { emissions) } \\
\mathrm{tCO}_{2} / \mathrm{yr}\end{array}$} & \multirow{2}{*}{$\begin{array}{c}\text { Total } \\
\text { annual } \\
\text { cost } \\
€ / y r\end{array}$} & \multicolumn{8}{|c|}{ Installed capacities $P I N$} & \multirow{2}{*}{$\begin{array}{c}\text { Marginal } \\
\text { cost } \\
€ / \mathrm{COO}_{2}\end{array}$} & \multirow{2}{*}{$\begin{array}{c}\text { Average } \\
\text { cost } \\
€ / \mathbf{t C O}_{2}\end{array}$} \\
\hline & & $\begin{array}{r}\mathbf{G E} \\
\mathbf{k} \mathbf{W}_{\mathrm{e}}\end{array}$ & $\begin{array}{l}\text { GB } \\
\mathbf{k W}\end{array}$ & $\begin{array}{l}\text { HP } \\
\text { kW }\end{array}$ & $\begin{array}{l}\text { ABS } \\
\mathbf{k W}\end{array}$ & $\begin{array}{l}\text { PV } \\
\mathbf{m}^{2}\end{array}$ & $\begin{array}{l}\text { ST } \\
\mathbf{m}^{2}\end{array}$ & $\begin{array}{c}\text { TSQ } \\
\text { kWh }\end{array}$ & $\begin{array}{l}\text { TSR } \\
\text { kWh }\end{array}$ & & \\
\hline (B) 155.1 & 105,067 & 4.2 & 204.8 & 162.1 & 94.0 & - & - & 0.4 & 39.9 & - & 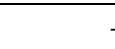 \\
\hline 145.0 & 105,126 & 3.5 & 193.5 & 176.8 & 83.8 & - & - & - & 40.0 & 5.9 & 5.9 \\
\hline 135.0 & 105,254 & 3.1 & 171.6 & 201.9 & 66.3 & - & - & - & 40.2 & 12.8 & 9.3 \\
\hline 125.0 & 105,453 & 1.1 & 169.0 & 209.8 & 60.9 & - & - & - & 40.2 & 19.9 & 12.8 \\
\hline 115.0 & 105,771 & - & 163.6 & 218.7 & 54.7 & - & - & - & 40.3 & 31.9 & 17.6 \\
\hline (C) 105.0 & 106,266 & - & 140.0 & 244.6 & 36.7 & - & - & - & 40.4 & 49.5 & 24.0 \\
\hline 100.0 & 106,690 & - & 113.6 & 273.6 & 16.6 & - & - & - & 40.6 & 84.7 & 29.5 \\
\hline 99.0 & 106,916 & - & 91.8 & 297.6 & - & 1.5 & - & - & 40.7 & 226.6 & 33.0 \\
\hline 97.0 & 107,745 & - & 91.8 & 297.6 & - & 88.1 & - & - & 40.7 & 414.4 & 46.1 \\
\hline 95.0 & 108,574 & - & 91.8 & 297.6 & - & 174.7 & - & - & 40.7 & 414.4 & 58.4 \\
\hline 93.0 & 109,403 & - & 91.8 & 297.6 & - & 261.3 & - & - & 40.7 & 414.4 & 69.9 \\
\hline 91.0 & 110,232 & - & 91.8 & 297.6 & - & 347.9 & - & - & 40.7 & 414.4 & 80.6 \\
\hline 89.0 & 111,060 & - & 91.8 & 297.6 & - & 434.4 & - & - & 40.7 & 414.4 & 90.7 \\
\hline 87.0 & 111,889 & - & 91.8 & 297.6 & - & 521.0 & - & - & 40.7 & 414.4 & 100.2 \\
\hline (D) 85.0 & 112,718 & - & 91.8 & 297.6 & - & 607.6 & - & - & 40.7 & 414.4 & 109.2 \\
\hline 84.0 & 113,170 & - & 86.6 & 303.3 & - & 640.0 & - & - & 35.3 & 452.0 & 114.0 \\
\hline 83.5 & 113,472 & - & 75.3 & 315.6 & - & 640.0 & - & - & 23.6 & 604.3 & 117.4 \\
\hline 83.0 & 113,932 & - & 74.5 & 316.6 & - & 634.9 & 7.1 & - & 22.7 & 919.2 & 123.0 \\
\hline 82.5 & 114,392 & - & 74.5 & 316.6 & - & 629.4 & 14.6 & - & 22.7 & 920.5 & 128.5 \\
\hline 82.3 & 114,631 & - & 72.6 & 316.6 & - & 626.8 & 18.2 & 1.9 & 22.7 & 953.8 & 131.3 \\
\hline 82.0 & 114,884 & - & 69.7 & 317.3 & - & 624.5 & 21.4 & 4.8 & 22.0 & 1012.7 & 134.4 \\
\hline 81.5 & 115,424 & - & 63.2 & 320.9 & - & 620.3 & 27.1 & 11.4 & 18.6 & 1080.2 & 140.8 \\
\hline 81.0 & 116,005 & - & 59.8 & 320.8 & 0.4 & 615.0 & 34.5 & 18.5 & 18.1 & 1163.3 & 147.7 \\
\hline 80.0 & 117,605 & - & 56.1 & 312.6 & 19.2 & 603.9 & 49.7 & 43.1 & - & 1599.3 & 167.0 \\
\hline 79.0 & 119,643 & - & 55.8 & 296.4 & 30.4 & 589.2 & 70.0 & 89.4 & - & 2038.6 & 191.6 \\
\hline 78.0 & 121,862 & - & 55.6 & 285.2 & 37.4 & 570.5 & 95.8 & 121.1 & 0.9 & 2218.4 & 217.9 \\
\hline 77.0 & 124,221 & - & 54.7 & 267.8 & 39.3 & 552.9 & 120.0 & 172.6 & 14.8 & 2359.3 & 245.4 \\
\hline 76.0 & 126,850 & - & 52.9 & 260.4 & 41.4 & 530.4 & 151.1 & 201.1 & 19.0 & 2629.2 & 275.5 \\
\hline 75.5 & 128,282 & - & 52.8 & 253.2 & 42.7 & 520.2 & 165.1 & 228.8 & 24.0 & 2863.0 & 291.8 \\
\hline 75.3 & 129,301 & - & 62.7 & 265.0 & 47.8 & 519.3 & 166.3 & 231.0 & 5.8 & 4076.3 & 303.6 \\
\hline 75.0 & 130,498 & - & 63.0 & 269.6 & 48.8 & 513.4 & 174.5 & 247.2 & - & 4789.6 & 317.6 \\
\hline 74.5 & 134,365 & - & 54.3 & 269.6 & 48.8 & 480.2 & 220.2 & 267.0 & - & 7734.3 & 363.7 \\
\hline (A) 74.2 & 137,630 & - & 49.3 & 269.6 & 48.8 & 461.2 & 246.5 & 314.0 & - & $12,562.0$ & 402.9 \\
\hline
\end{tabular}


Table 7: Single-objective solutions and selected trade-off solutions comparison.

\begin{tabular}{|c|c|c|c|c|c|c|}
\hline \multicolumn{3}{|c|}{ Results } & \multirow{2}{*}{$\begin{array}{c}\begin{array}{c}\text { Min. } \\
\text { Economic } \\
\text { cost }(\mathbf{B})\end{array} \\
4.2\end{array}$} & \multirow{2}{*}{$\begin{array}{c}\begin{array}{c}\text { Min. } \\
\mathrm{CO}_{2} \\
\text { emissions } \\
\text { (A) }\end{array} \\
-\end{array}$} & \multirow{2}{*}{$\begin{array}{c}\text { Preferred } \\
\text { trade-off } \\
\text { (C) }\end{array}$} & \multirow{2}{*}{$\begin{array}{c}\text { Bold } \\
\text { trade-off } \\
\text { (D) } \\
\end{array}$} \\
\hline GE & Cogeneration module & $\mathrm{kW}$ & & & & \\
\hline GB & Gas boiler & $\mathrm{kW}$ & 204.8 & 49.3 & 140.0 & 91.8 \\
\hline HP & Reversible heat pump & $\mathrm{kW}$ & 162.1 & 269.6 & 244.6 & 297.6 \\
\hline ABS & Absorption chiller & $\mathrm{kW}$ & 94.0 & 48.8 & 36.7 & - \\
\hline PV & Photovoltaic panels & $\mathrm{m}^{2}$ & - & 461.2 & - & 607.6 \\
\hline ST & Solar thermal collectors & $\mathrm{m}^{2}$ & - & 246.5 & - & - \\
\hline TSQ & Hot water storage tank & $\mathrm{kWh}$ & 0.4 & 314.0 & - & - \\
\hline TSR & Chilled water storage tank & $\mathrm{kWh}$ & 39.9 & - & 40.4 & 40.7 \\
\hline \multicolumn{3}{|c|}{ Natural gas consumption, $\mathrm{MWh} / \mathrm{yr}$} & 363.3 & 0.1 & 88.1 & 52.8 \\
\hline \multicolumn{3}{|c|}{ Purchased electricity, MWh/yr } & 355.0 & 355.9 & 466.6 & 356.7 \\
\hline \multicolumn{3}{|c|}{ Sold electricity, MWh/yr } & - & -9.3 & - & -18.1 \\
\hline \multicolumn{3}{|c|}{ Annual operation cost, $€ / \mathrm{yr}$} & $75,225.0$ & $53,108.7$ & $77,548.6$ & $54,672.6$ \\
\hline \multicolumn{3}{|c|}{ Annual fixed cost, $€ / y r$} & $29,841.9$ & $84,521.6$ & $28,717.7$ & $58,045.6$ \\
\hline \multicolumn{3}{|c|}{ Total annual cost, $€ / \mathrm{yr}$} & $105,066.9$ & $137,630.2$ & $106,266.3$ & $112,718.2$ \\
\hline \multicolumn{3}{|c|}{$\begin{array}{l}\text { Annual operation } \mathrm{CO}_{2} \text { emissions, } \\
\mathrm{kgCO}_{2} / \mathrm{yr}\end{array}$} & $152,275.9$ & $61,558.5$ & $102,063.8$ & $73,304.3$ \\
\hline \multicolumn{3}{|c|}{ Annual fixed $\mathrm{CO}_{2}$ emissions, $\mathrm{kgCO}_{2} / \mathrm{yr}$} & 2789.8 & $12,681.6$ & 2936.2 & $11,695.7$ \\
\hline \multicolumn{3}{|c|}{ Total annual $\mathrm{CO}_{2}$ emissions, $\mathrm{kgCO}_{2} / \mathrm{yr}$} & $155,066.7$ & $74,240.1$ & $105,000.0$ & $85,000.0$ \\
\hline \multicolumn{3}{|c|}{ Average cost (from solution $\mathrm{B}$ ), $€ / \mathrm{tCO}_{2}$} & - & 402.9 & 24.0 & 109.2 \\
\hline
\end{tabular}


Table 8: Sensitivity analysis for natural gas prices in the economic optimal solution.

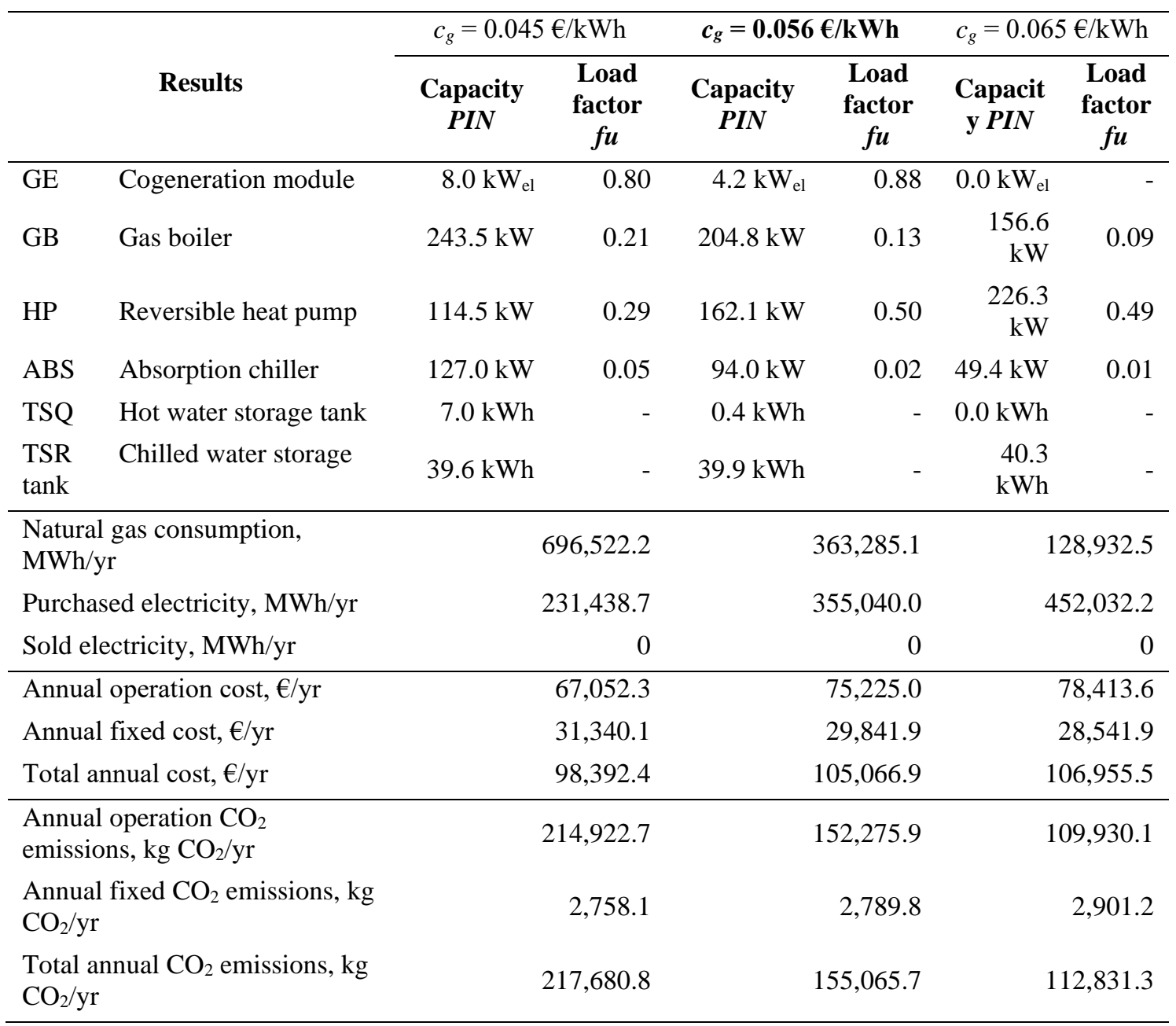


Table 9: Sensitivity analysis for PV bare module costs in the economic optimal solution.

\begin{tabular}{|c|c|c|c|c|c|}
\hline \multirow{2}{*}{\multicolumn{2}{|c|}{ Results }} & \multicolumn{2}{|c|}{$C I(P V)=209 € / \mathrm{m}^{2}$} & \multicolumn{2}{|c|}{$C I(P V)=264 € / \mathrm{m}^{2}$} \\
\hline & & $\begin{array}{l}\text { Capacity } \\
\text { PIN }\end{array}$ & $\begin{array}{l}\text { Load factor } \\
\qquad f u\end{array}$ & $\begin{array}{l}\text { Capacity } \\
\text { PIN }\end{array}$ & $\begin{array}{l}\text { Load factor } \\
\qquad f u\end{array}$ \\
\hline GE & Cogeneration module & $4.2 \mathrm{~kW}_{\mathrm{el}}$ & 0.88 & $4.2 \mathrm{~kW}_{\mathrm{el}}$ & 0.88 \\
\hline GB & Gas boiler & $204.8 \mathrm{~kW}$ & 0.13 & $204.8 \mathrm{~kW}$ & 0.13 \\
\hline HP & Reversible heat pump & $162.1 \mathrm{~kW}$ & 0.50 & $162.1 \mathrm{~kW}$ & 0.50 \\
\hline PV & Photovoltaic panels & $640 \mathrm{~m}^{2}$ & 0.17 & $0 \mathrm{~m}^{2}$ & - \\
\hline $\mathrm{ABS}$ & Absorption chiller & $94.0 \mathrm{~kW}$ & 0.02 & $94.0 \mathrm{~kW}$ & 0.02 \\
\hline TSQ & Hot water storage tank & $0.4 \mathrm{kWh}$ & - & $0.4 \mathrm{kWh}$ & - \\
\hline TSR & Chilled water storage tank & $39.9 \mathrm{kWh}$ & - & $39.9 \mathrm{kWh}$ & - \\
\hline \multicolumn{2}{|c|}{ Natural gas consumption, $\mathrm{MWh} / \mathrm{yr}$} & & $363,273.0$ & & $363,285.1$ \\
\hline \multicolumn{2}{|c|}{ Purchased electricity, MWh/yr } & & $237,210.2$ & & $355,040.0$ \\
\hline \multicolumn{2}{|c|}{ Sold electricity, MWh/yr } & & 30.812 .4 & & 0 \\
\hline \multicolumn{2}{|c|}{ Annual operation cost, $€ / \mathrm{yr}$} & & $50,996.9$ & & $75,225.0$ \\
\hline \multicolumn{2}{|c|}{ Annual fixed cost, $€ / y r$} & & $53,947.5$ & & $29,841.9$ \\
\hline \multicolumn{2}{|c|}{ Total annual cost, $€ / y r$} & & $104,944.3$ & & $105,066.9$ \\
\hline \multicolumn{2}{|c|}{$\begin{array}{l}\text { Annual operation } \mathrm{CO}_{2} \text { emissions, } \mathrm{kg} \\
\mathrm{CO}_{2} / \mathrm{yr}\end{array}$} & & $128,368.9$ & & $152,275.9$ \\
\hline \multicolumn{2}{|c|}{$\begin{array}{l}\text { Annual fixed } \mathrm{CO}_{2} \text { emissions, } \mathrm{kg} \\
\mathrm{CO}_{2} / \mathrm{yr}\end{array}$} & & $11,909.8$ & & $2,789.8$ \\
\hline \multicolumn{2}{|c|}{$\begin{array}{l}\text { Total annual } \mathrm{CO}_{2} \text { emissions, } \mathrm{kg} \\
\mathrm{CO}_{2} / \mathrm{yr}\end{array}$} & & $140,278.7$ & & $155,065.7$ \\
\hline
\end{tabular}




\section{Figure legends}

Figure 1. Multi-objective synthesis framework of energy supply systems.

Figure 2. Superstructure of the trigeneration system.

Figure 3. Hourly $\mathrm{CO}_{2}$ emission factors of the electricity in the Spanish electric grid for each representative day of the year, in $\mathrm{kgCO}_{2} / \mathrm{kWh}$.

Figure 4. Installed capacities and annual energy flows - Optimal total annual cost solution.

Figure 5. Hourly energy flows in January - Optimal total annual cost.

Figure 6. Hourly energy flows in July - Optimal total annual cost.

Figure 7. Installed capacities and annual energy flows - Optimal total annual $\mathrm{CO}_{2}$ emissions solution.

Figure 8. Hourly energy flows in January - Optimal total annual $\mathrm{CO}_{2}$ emissions.

Figure 9. Hourly energy flows in July - Optimal total annual $\mathrm{CO}_{2}$ emissions.

Figure 10. Pareto set considering the annual economic cost and the annual $\mathrm{CO}_{2}$ emissions.

Figure 11. Pareto sets for different values of natural gas price.

Figure 12. Pareto sets for different values of total rooftop area.

Figure 13. Total rooftop area occupied by PV and ST in the environmental optimal solution. 